\title{
Backbone and Side-Chain Specific Dissociations of $z$ Ions from Non-Tryptic Peptides
}

\author{
Thomas W. Chung and František Tureček \\ Department of Chemistry, Bagley Hall, Box 351700, University of Washington, Seattle, Washington, USA
}

Backbone $z$-type fragment ions formed by electron-transfer dissociation (ETD) of doubly protonated peptides AAHAL, AHDAL, and AHADL were subjected to collisional activation and their dissociation products were studied by ETD-CID-MS ${ }^{3}$ and MS $^{4}$. Electron structure theory calculations were performed to elucidate ion structures and reaction mechanisms. All $z$ ions showed competitive eliminations of $\mathrm{C}_{3} \mathrm{H}_{7}$ and $\mathrm{C}_{4} \mathrm{H}_{8}$ from the $\mathrm{C}$-terminal Leu side chain. The energetics and kinetics of these dissociations were studied computationally for the $z_{4}$ ion from AAHAL, and optimized structures are reported for several intermediates and transition states. RRKM calculations on the combined B3LYP and PMP2/6-311++G(2d,p) potential energy surface provided unimolecular rate constants that closely reproduced the experimental branching ratios for $\mathrm{C}_{3} \mathrm{H}_{7}$ and $\mathrm{C}_{4} \mathrm{H}_{8}$ eliminations. Mechanisms were also studied for the loss of $\mathrm{CO}_{2}$ from $z$ ions generated by ETD of AHDAL and AHADL and for a specific radicalinduced Asp- $\mathrm{C}_{\alpha}-\mathrm{CO}$ backbone cleavage. CID of the $z$ ions under study did not produce any fragment ions that would indicate cascade backbone dissociations triggered by the radical sites. In contrast, the majority of backbone dissociations occurred at bonds that were remote from the radical sites (spin-remote dissociations) and were triggered by proton migrations that were analogous to those considered for standard peptide ion fragmentations. (J Am Soc Mass Spectrom 2010, 21, 1279-1295) (c) 2010 American Society for Mass Spectrometry

$\mathrm{D}$ issociations of peptide ions induced by electron-transfer produce series of $\mathrm{N}$-terminal fragments ( $c$ type ions) and C-terminal fragments ( $z$ type ions, Scheme 1) [1-3]. Distinguishing these two types of fragments is important for determining the peptide sequence and, in proteomics studies, identifying the protein of interest. The $c$ and $z$ type fragments are unequivocally distinguished by their electron parity, which is even for $c$ ions and odd for $z$ ions. This is reflected in the ion elemental composition according to the nitrogen rule [4]. This fundamental feature has been reiterated by Coon and coworkers [5] but its implementation requires high mass resolution measurements to establish the ion elemental composition. An alternative approach relies on $\mathrm{MS}^{n}$ analysis using collision induced dissociation (CID) or infrared multiphoton dissociation (IRMPD) of $c$ and $z$ ions produced by electrontransfer dissociation (ETD) and stored in an ion trap. Recently, McLuckey and coworkers reported a survey of collision induced dissociations of $z$ ions produced by ETD of a series of peptides [6]. In particular, these authors identified several radical-induced side-chain dissociations that were specific for particular amino acid residues. Side-chain losses occurring in electron capture dissociation have also been studied by several

Address reprint requests to Dr. F. Tureček, Department of Chemistry, University of Washington, Bagley Hall, Box 351700, Seattle, WA 98195-1700, USA. E-mail: turecek@chem.washington.edu groups and shown to provide additional structure information [7-12].

The reaction mechanisms for side-chain dissociations remain largely tentative, mainly because the structures of $c$ and $z$ ions are mostly unknown. $c$-Type ions are as a rule represented as peptides $\mathrm{C}$-terminated with an enolimine or the thermochemically more stable amide moiety [13]. A recent infrared multiphoton dissociation study using a tunable free-electron laser identified a small $c$ ion from a charge-tagged peptide as an amide [14], possibly formed by exothermic isomerization of an enolimine [15]. $z$-Type ions are usually represented as $C_{\alpha}$ radicals, which are stable in the gas phase [16].

The goal of the present work is to analyze by experiment and electron structure theory the structures, mechanisms, and dissociation kinetics of $z$ ions produced by ETD. We chose three model pentapeptides, AAHAL, AHDAL, and AHADL, which are of interest because they display specific dissociations involving the histidine and leucine residues and also show different reactivities of the C-terminal and aspartic acid carboxyl groups. Another interesting feature of these peptides is that they show dramatic differences between dissociations induced by electron capture and those induced by electron-transfer [17]. The nature of $z$ ion dissociations is also of interest from the point of view of dissociation mechanisms in electron-based methods. In particular, $\mathrm{O}^{\prime}$ Connor and coworkers pro- 


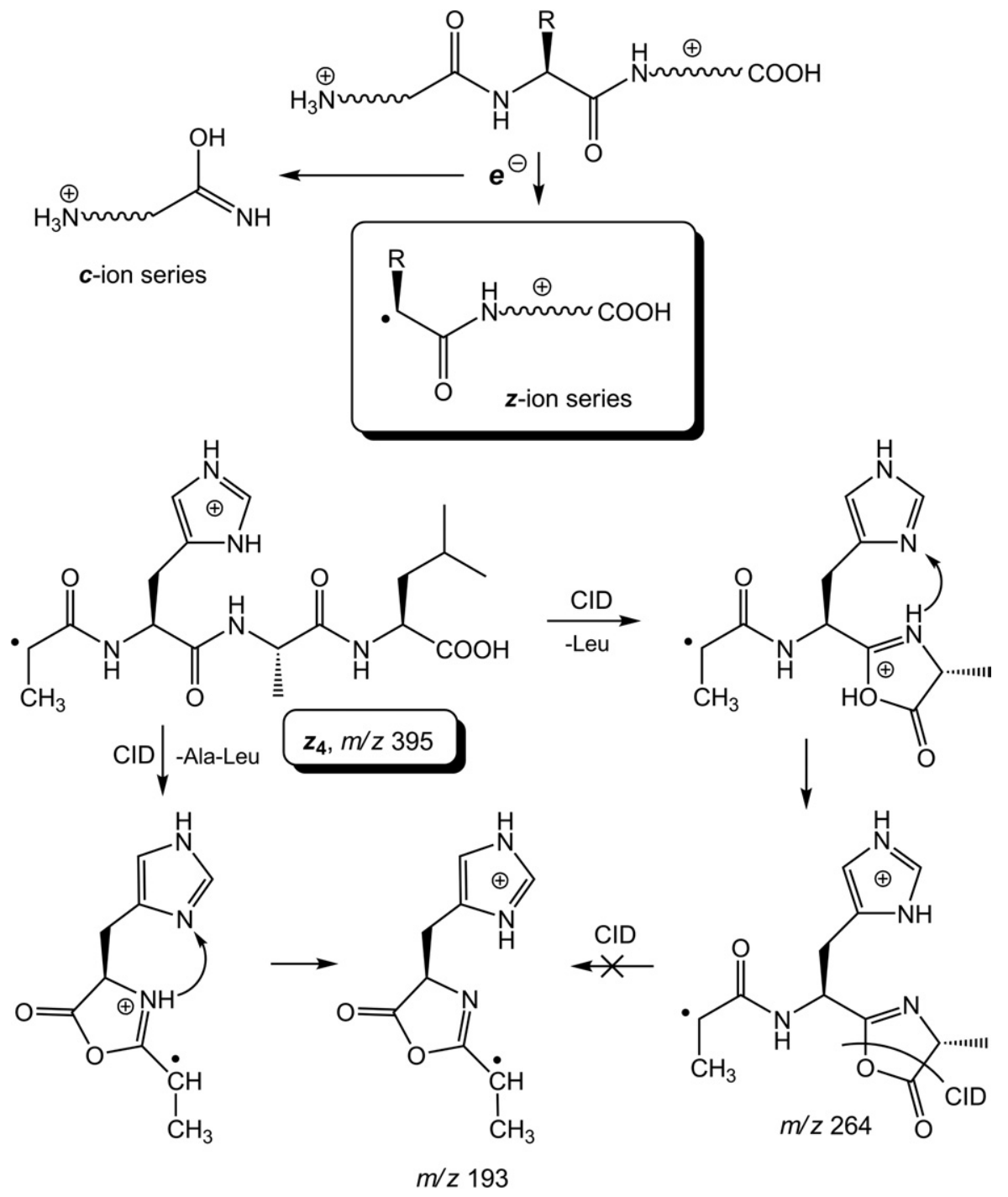

Scheme 1

posed a cascade scheme to explain electron capture dissociations of cyclic peptide ions in which a rupture of the peptide macrocyclic ring by an $\mathrm{N}-\mathrm{C}_{\alpha}$ bond cleavage was followed by subsequent rearrangements and dissociations producing backbone fragments [18]. Although the specific mechanistic nature of this scheme has not been studied, it can possibly operate in linear peptides where consecutive dissociations of larger primary $z$ fragments would yield smaller, secondary, $z$ ions to appear in the spectrum.

The paper is organized as follows. First, we will present experimental data on ETD/MS ${ }^{\mathrm{n}}$ activation of $z$ ions from doubly charged AAHAL, AHDAL, and AHADL ions. Then we analyze by ab initio and density functional theory computations the structures of selected $z$ ions and transition states for their isomerizations and dissociations. Finally, we use RRKM theory to assess the kinetics of unimolecular rearrangements and dissociations of select $z$ ions.

\section{Experimental}

\section{Materials and Methods}

The peptides AAHAL, AHDAL, and AHADL ( $>95 \%$ pure) were purchased from GenScript and their sequence was checked by electrospray MS/MS.

Electron-transfer dissociation mass spectra were obtained on a Thermo-Fisher (San Jose, CA, USA) LTQ linear ion trap mass spectrometer equipped with an electrospray ion source and a chemical ionization source for the production of fluoranthene anion radicals. Peptide ions were produced by electrospray from $50 / 50$ methanol-water solutions containing $1 \%$ of acetic acid. Typically, 5-10 $\mu \mathrm{M}$ peptide solutions were electrosprayed at $1.6-2.5 \mu \mathrm{L} / \mathrm{min}$ flow rates to form abundant doubly charged ions, $(\mathrm{M}+2 \mathrm{H})^{2+}$, which were accumulated in the ion trap and selected by their $\mathrm{m} / \mathrm{z}$ ratios. The mass selection window was 2 mass units to include nearest ${ }^{13} \mathrm{C}$ isotopologues. Electron-transfer dis- 
sociation was accomplished at 100 and 200 ms ion-ion interaction time. $z$-Type ions from ETD were massselected and collisionally dissociated. The ion excitation energy was set at $20 \%$ to $35 \%$ on the instrument scale.

\section{Calculations}

Standard ab initio and density functional theory calculations were performed using the Gaussian 03 suite of programs [19]. Geometries were optimized with the hybrid B3LYP functional [20] using the 6-31+G(d,p) basis set. Stationary points were characterized by harmonic frequency calculations to identify local energy minima (all real frequencies) and first-order saddle points (one imaginary frequency). Additional sets of energies were obtained by single-point calculations using B3LYP and the Møller-Plesset perturbational theory [21] (second-order, frozen core) with the larger $6-311++G(2 d, p)$ basis set. For the pentapeptide ions under study (71-74 atoms) the basis set consisted of 1761-1878 primitive Gaussians and the MP2 calculations required $>50$ Gbyte scratch space. Calculations on all open-shell species (radicals and cation-radicals) used the spin-unrestricted formalism. Spin contamination was quite modest in most cases and was treated by Schlegel's spin annihilation protocol [22]. The B3LYP and spin-projected MP2 (PMP2) energies were averaged (B3-PMP2) to compensate for small errors inherent to both approximations according to the procedure reported previously [23]. Unimolecular rate constants were calculated using the Rice-Ramsperger-KasselMarcus (RRKM) theory [24] and employing a modified Hase's program [25], which was recompiled for Windows XP [26]. The RRKM rate constants were obtained by direct count of quantum states at internal energies that were increased in $2 \mathrm{~kJ} \mathrm{~mol}^{-1}$ steps from the transition-state up to $400 \mathrm{~kJ} \mathrm{~mol}^{-1}$ above the reactant. Rotations were treated adiabatically and the calculated microscopic rate constants $k(E, J, K)$ were then Boltzmann-averaged over the thermal distribution of rotational states at $298 \mathrm{~K}$.

\section{Results}

ETD of doubly charged AAHAL, AHDAL, and AHADL peptide ions were found to produce $c$ - and $z$-ion series from dissociations of all four amide $\mathrm{N}-\mathrm{C}_{\alpha}$ bonds (Figure $1)$. Note that the charge always remained in the histidine containing fragment. In addition, ETD resulted in abundant loss of ammonia from the charge-reduced ions, which most likely involved the N-terminal ammonium group [27]. Thus, these fragment ions were considered to be $\mathrm{C}_{\alpha}$ radicals analogous to the other $z$ ions and are denoted as $z_{5}$ (Figure 1 ). The relative intensities of the charge-reduced ions and backbone $c$ and $z$ fragments practically did not change $( \pm 10 \%)$ when the ion-ion interaction time was increased from 100 to $200 \mathrm{~ms}$.

\section{AAHAL}

The $z$ ions from AAHAL $\left(z_{5}\right.$ at $m / z 466, z_{4}$ at $m / z$ 395, and $z_{3}$ at $m / z$ 324) were further analyzed by CID spectra. CID of the $z$ ions from AAHAL showed loss of water as a common dissociation. More interestingly, the $z$ ions lost $\mathrm{C}_{3} \mathrm{H}_{7}$ radicals (43 Da loss) and $\mathrm{C}_{4} \mathrm{H}_{8}$ molecules (56 Da loss), which originated from the leucine side chain [11]. These major fragments appear at $m / z 423$ and 410 in the ETD-CID spectrum of the $z_{5}$ ion (Figure 2a), at $m / z 352$ and 339 from $z_{4}$ (Figure $2 b$ ), and at $m / z 281$ and 268 from $z_{3}$ (Figure 2c). The branching ratios for the $\mathrm{C}_{4} \mathrm{H}_{8}$ and $\mathrm{C}_{3} \mathrm{H}_{7}$ loss, $\left[z_{\mathrm{n}}-\mathrm{C}_{4} \mathrm{H}_{8}\right] /\left[z_{\mathrm{n}}-\mathrm{C}_{3} \mathrm{H}_{7}\right]$ depended on the $z$ ion and increased by a factor of two from 0.26 for $z_{5}$ to 0.52 and 1.1 for $z_{4}$, and $z_{3}$, respectively. We will address the detailed mechanism and kinetics of these competitive eliminations later. Another series of $z$-ion dissociations was due to backbone cleavages. Thus, CID of the $z_{5}$ ion gave $\mathrm{MS}^{3}$ fragments at $m / z 335$ and 264 that corresponded to eliminations of Leu and Ala-Leu neutral molecules, respectively (Figure 2a). Likewise, CID of the $z_{4}$ ion gave $m / z 264$ and 193 fragments by elimination of Leu and Ala-Leu molecules, respectively (Figure $2 b$ ), and CID of the $z_{3}$ ion gave $\mathrm{m} / z 193$ by elimination of the Leu molecule (Figure 2c). The eliminations of Leu and Ala-Leu from the $z_{5}$ and $z_{4}$ ions occur competitively, not consecutively. This was established by an ETD-CID-MS ${ }^{4}$ spectrum of the $\mathrm{m} / \mathrm{z} 264$ fragment prepared by loss of Leu from the $z_{4}$ ion that showed a dominant elimination of a $44 \mathrm{Da}$ neutral fragment, presumably $\mathrm{CO}_{2}$, to give $\mathrm{m} / \mathrm{z} 220$ but no formation of the $m / z 193$ fragment. Note that the elimination of Leu was always more facile than elimination of Ala-Leu.

The eliminations of neutral Leu and Ala-Leu molecules presumably proceed by mechanisms similar to those for the formation of $\boldsymbol{b}$-type ions [28], which require proton migration to the departing amino acid or peptide molecule. The fact that the amide bond more remote from the His residue is more prone to dissociate indicates the formation of oxazolone structures as shown for the $z_{4}$ ion in Scheme 1 [29]. The subsequent elimination of $\mathrm{CO}_{2}$ is compatible with the formation of a neutral oxazolone ring $\left(\mathrm{PA}=877 \mathrm{~kJ} \mathrm{~mol}^{-1}\right)$ [30] while the charging proton is presumably transferred to the far more basic imidazole ring $\left(\mathrm{PA}=946 \mathrm{~kJ} \mathrm{~mol}^{-1}\right)$. Alternative mechanisms, e.g., neighboring participation by the His imidazole ring in the amide backbone dissociation, as considered previously [31, 32], would be expected to favor cleavage closer to the His residue and loss of Ala-Leu to form a five-membered ring intermediate, whereas loss of Leu would require an eight- or nine-membered intermediate. An interesting feature of Scheme 1 dissociations is that the remote $C_{\alpha}$ radical site in the $z$ ion is not engaged in the amide bond cleavage. Thus, these dissociations can be viewed as spin-remote ion fragmentations, a concept we introduced previously for metal-containing cation-radicals [33]. 

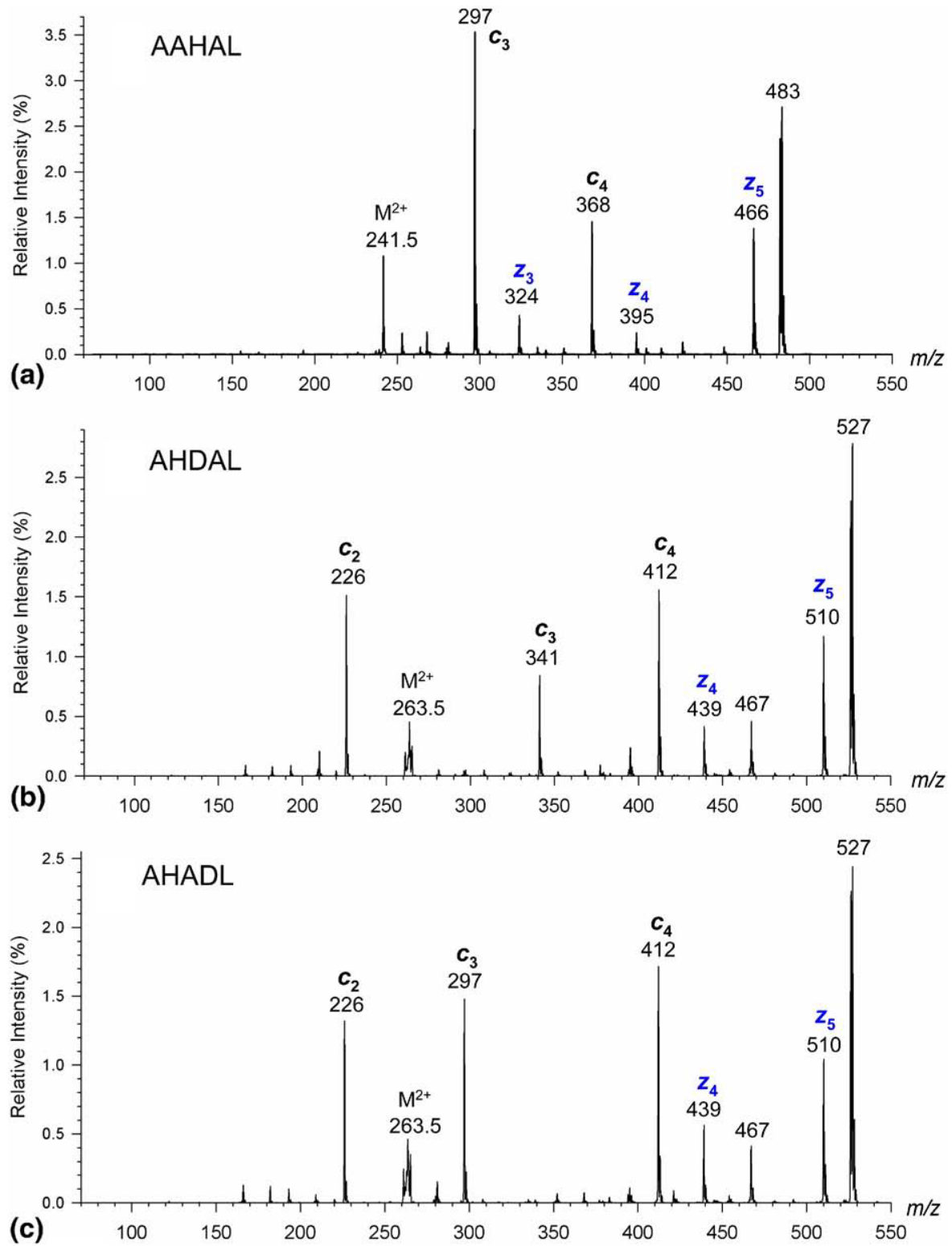

Figure 1. Electron-transfer dissociation mass spectra of doubly charged ions from (a) AAHAL, (b) AHDAL, and (c) AHADL.

\section{AHDAL and AHADL}

The $z$ ions from AHDAL and AHADL $\left(z_{5}\right.$ at $m / z 510$ and $z_{4}$ at $\mathrm{m} / \mathrm{z} 439$ ) were investigated by obtaining the ETD-CID-MS ${ }^{3}$ spectra (Figure $3 \mathrm{a}-\mathrm{d}$ ). CID of the $z_{5}$ ions showed a dominant loss of $\mathrm{C}_{3} \mathrm{H}_{7}(\mathrm{~m} / \mathrm{z} 467)$, common eliminations of water $(\mathrm{m} / \mathrm{z} 492), \mathrm{CO}_{2}(\mathrm{~m} / \mathrm{z} 466), \mathrm{C}_{4} \mathrm{H}_{8}$ $(\mathrm{m} / \mathrm{z} 454)$, and His containing sequence fragments at $\mathrm{m} / \mathrm{z}$ 379, 264, 193, and 166 (Figure 3a, b). No $z_{4}$ fragment formation from the $z_{5}$ ions was observed at $\mathrm{m} / \mathrm{z} 439$, indicating that the cascade mechanism was not competitive in this case. The main distinguishing feature of the CID spectra of the $z_{5}$ ions was the presence of fragments at $\mathrm{m} / \mathrm{z} 352$ from the AHADL sequence and at $\mathrm{m} / \mathrm{z} 281$ from the AHDAL sequence. The $m / z 281$ ion was further investigated by obtaining an ETD-CID-MS ${ }^{4}$ spectrum, which showed losses of water and $\mathrm{CO}_{2}$ and a dominant formation of an $\mathrm{m} / \mathrm{z} 194$ fragment ion by loss of $87 \mathrm{Da}$. The $\mathrm{CO}_{2}$ loss indicated that the $\mathrm{m} / z 281$ ion probably retained a carboxyl group, and its charge by protonation indicated retention of the basic histidine residue. The formation of the $\mathrm{m} / \mathrm{z} 281$ fragment ion can be rationalized by a common mechanism, which is shown for the latter ion in Scheme 2. This mechanism presumes a radical-induced migration of an Asp $\beta$-hydrogen atom (shown in blue in Scheme 2) onto the N-terminal $\mathrm{C}_{\alpha}$ radical site. The intermediate then undergoes a radical-induced $\beta$-scission of the Asp $\mathrm{C}_{\alpha}-\mathrm{CO}$ bond to eliminate a $C$-terminal radical and forming the evenelectron $\mathrm{m} / \mathrm{z} 281$ fragment ion. The dominant loss of an 87 Da neutral fragment upon further collisional activa- 


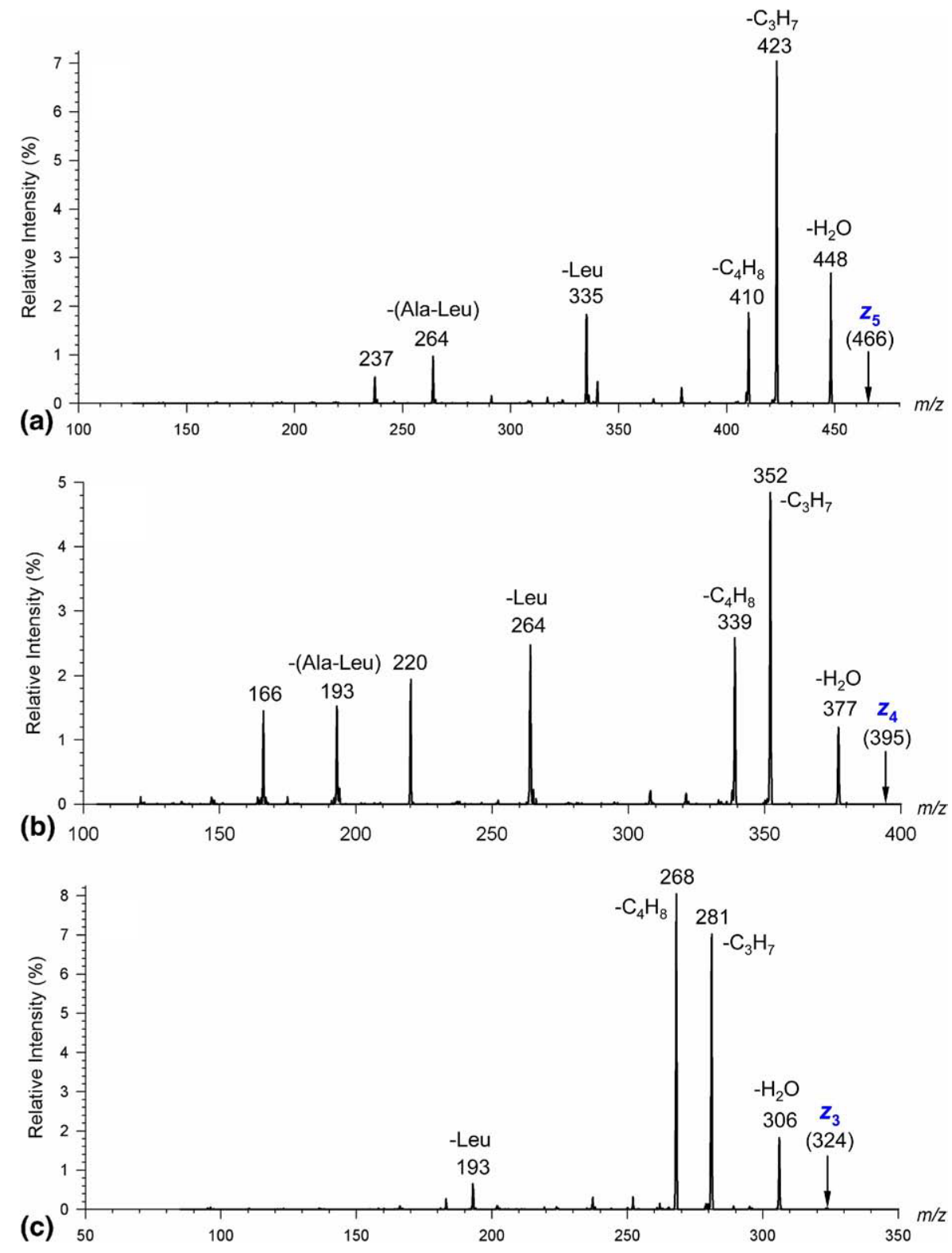

Figure 2. ETD-CID-MS ${ }^{3}$ mass spectra of (a) $z_{5}$, (b) $z_{4}$, and (c) $z_{3}$ fragment ions from AAHAL.

tion of the $m / z 281$ ion can be explained by elimination of $\beta$-aminoacrylic acid from the modified aspartic acid residue (Scheme 2). The $\mathrm{m} / \mathrm{z} 194$ ion is shown as an imidazole protonated tautomer, which is expected to be more stable than the oxazolone protonated isomer (vide supra). The formation of the homologous $\mathrm{m} / \mathrm{z} 352 \mathrm{frag}$ ment ion from the AHADL $z_{5}$ precursor can be depicted by an analogous scheme that involves transfer of an Asp $\beta$-hydrogen atom followed by $\beta$-scission of the Asp $\mathrm{C}_{\alpha}-\mathrm{CO}$ bond. The energetics of this mechanism as well as the structures of relevant intermediates were analyzed in more detail for $z_{4}$ ions from ETD-CID-MS ${ }^{3}$ of AHDAL (vide infra).

CID of the isomeric $z_{4}$ ions, $\mathrm{HADL}$, and $\mathrm{HDAL}(\mathrm{m} / \mathrm{z}$ 439) showed common losses of water $(\mathrm{m} / \mathrm{z} 421), \mathrm{C}_{3} \mathrm{H}_{7}$ $\left(m / z\right.$ 396) $, \mathrm{CO}_{2},(\mathrm{~m} / \mathrm{z} 395), \mathrm{C}_{4} \mathrm{H}_{8}(\mathrm{~m} / \mathrm{z} 383)$, and their combinations $(m / z 352,339)$. In addition, CID formation of specific homologous sequence ions at $\mathrm{m} / \mathrm{z} 281$ and 210 for HADL and HDAL, respectively, was observed (Figure 3c, d). According to the Scheme $\mathbf{2}$ mechanism, in both cases the backbone cleavage occurs at the Asp $\mathrm{C}_{\alpha}-\mathrm{CO}$ bond, and the $\mathrm{m} / \mathrm{z} 281$ ion retains a truncated HAD sequence whereas the $\mathrm{m} / \mathrm{z} 210$ ion retains a truncated HD sequence in which the Asp residues have been modified into $\beta$-aminoacrylic acid. Accordingly, CID of the $m / z 281$ fragment ion shows a dominant loss of $87 \mathrm{Da}$, presumably $\beta$-aminoacrylic acid from the modified Asp residue.

We note that the eliminations of $\mathrm{C}_{3} \mathrm{H}_{7}$ and $\mathrm{CO}_{2}$ from the $z_{4}$ ions are competitive but do not show much dependence on the peptide sequence. Compared to CID of the $z_{5}$ ions, the loss of $\mathrm{CO}_{2}$ is substantially enhanced 


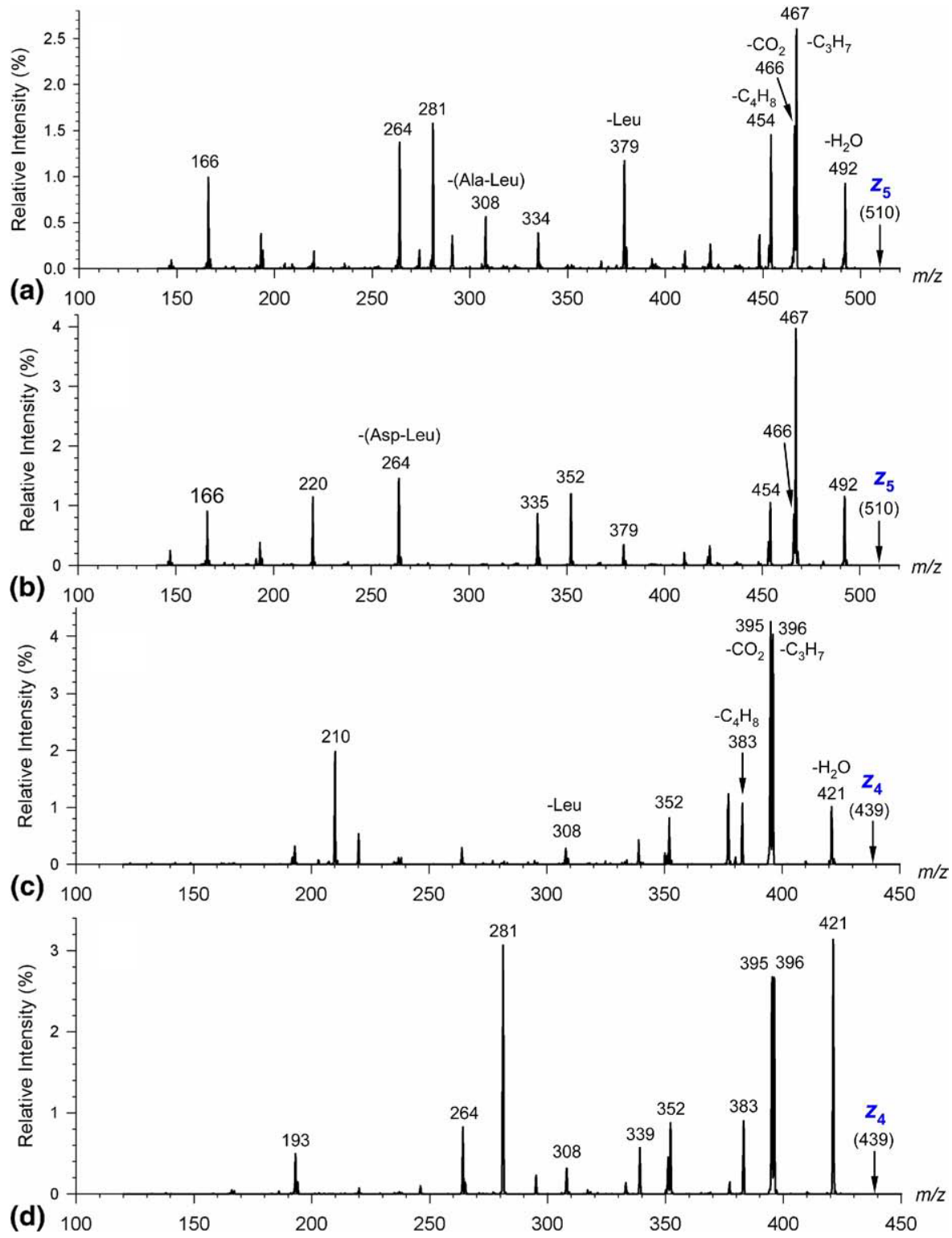

Figure 3. ETD-CID-MS ${ }^{3}$ mass spectra of $z_{5}$ fragment ions from (a) AHDAL and (b) AHADL, and $z_{4}$ fragment ions from (c) AHDAL and (d) AHADL.

in the shorter $z_{4}$ fragments. The largest difference in the CID spectra of the isomeric $z_{4}$ ions is the elimination of water, which is much more abundant from the HADL ion. The facile loss of water from the latter ion may be due to an interaction of the Asp and C-terminal carboxyl groups, but it was not studied here in detail.

\section{Energetics of AAHAL $z_{4}$ Ion Dissociations}

To recapitulate the ETD-CID-MS ${ }^{3}$ spectra, the major dissociations observed upon collisional activation of $z$ ions were loss of $\mathrm{C}_{3} \mathrm{H}_{7}$ and elimination of $\mathrm{C}_{4} \mathrm{H}_{8}$, which occurred in all ions studied here regardless of their length and sequence. The $z$ ions containing the Asp residue competitively underwent elimination of $\mathrm{CO}_{2}$ and specific backbone cleavages of the Asp $\mathrm{C}_{\alpha}-\mathrm{CO}$ bonds. We now analyze the energetics and kinetics of these dissociations for $z_{4}$ ions from AAHAL and AHDAL using electron structure theory and RRKM calculations of unimolecular rate constants.

\section{AAHAL}

The eliminations of $\mathrm{C}_{3} \mathrm{H}_{7}$ and $\mathrm{C}_{4} \mathrm{H}_{8}$ occur from the Leu side chain [7-12]. Since strong $\mathrm{C}-\mathrm{C}$ bonds are to be broken, it is presumed that these dissociations are preceded by $\mathrm{H}$ atom migrations that activate the $\mathrm{C}_{\beta}-\mathrm{C}_{\gamma}$ bond for the loss of $\mathrm{C}_{3} \mathrm{H}_{7}$ and the $\mathrm{C}_{\alpha}-\mathrm{C}_{\beta}$ bond for the loss of $\mathrm{C}_{4} \mathrm{H}_{8}$ [11]. The optimized geometry of the $z_{4}$ ion (1, Scheme 3, Scheme S1, Supplementary Material, which can be found in the electronic version of this article), indicates that the Ala- $\mathrm{C}_{\alpha}$ radical center is re- 
<smiles>CCC(=O)N[C@@H](Cc1cnc[nH]1)C(=O)N[C@H](C(=O)N[C@@H](C)C(=O)N[C@@H](CC(C)C)C(=O)O)[C@H](C)C(=O)O</smiles>

AHDAL, $\mathbf{z}_{5}, m / z 510$<smiles>CC(C)C[C@H](NC(=O)[C@H](C)NC(=O)CNC(=O)[C@H](Cc1cnc[nH]1)NC(=O)C(C)C)C(=O)O</smiles>

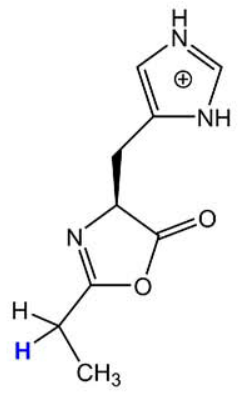

$m / z 194$

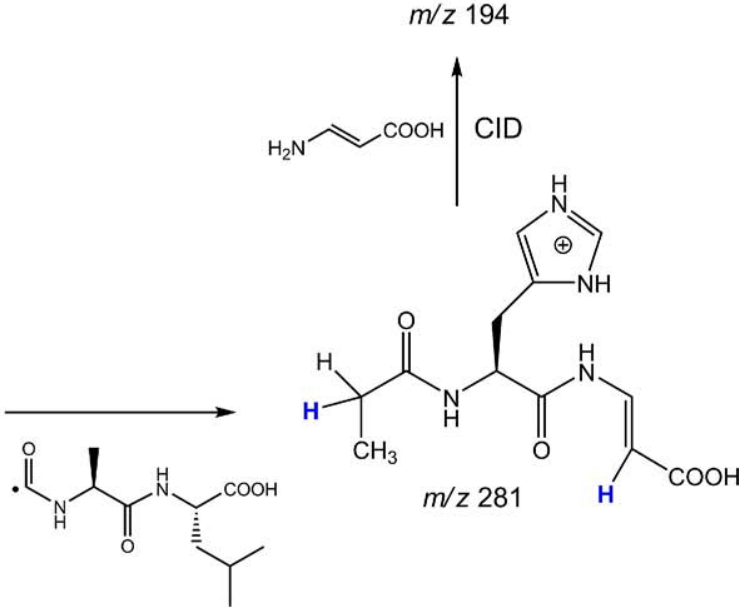

Scheme 2

mote from both the Leu $\mathrm{C}_{\alpha}-\mathrm{H}$ bond and the side-chain $\mathrm{C}-\mathrm{H}$ bonds. Conformational changes in $\mathbf{1}$ are necessary to bring the $\mathrm{C}_{\alpha}$ radical center and the Leu $\mathrm{C}_{\alpha}-\mathrm{H}$ bond within a bonding distance. However, these are hampered by the rigid trans-amide backbone, so that reaching the transition-state for the Leu- $\mathrm{C}_{\alpha}-\mathrm{H} \rightarrow$ Ala- $\mathrm{C}_{\alpha}$ transfer is accompanied by substantial distortions of the dihedral angles (Scheme S1) and requires $132 \mathrm{~kJ} \mathrm{~mol}^{-1}$ in the transition-state (TS1, Table 1). The Leu- $\mathrm{C}_{\alpha}-\mathrm{H} \rightarrow$ Ala- $\mathrm{C}_{\alpha}$ transfer is $34 \mathrm{~kJ} \mathrm{~mol}^{-1}$ exothermic to form the Leu- $\mathrm{C}_{\alpha}$ radical isomer 2 (Table 1 , Scheme S1). Dissociation of the Leu $C_{\beta}-C_{\gamma}$ bond in 2 proceeds through a late transition-state (TS2 at $132 \mathrm{~kJ} \mathrm{~mol}^{-1}$ above 2) and results in the loss of a $\mathrm{C}_{3} \mathrm{H}_{7}$ radical and formation of the $\mathrm{m} / \mathrm{z} 352$ fragment ion (3). Overall, the loss of $\mathrm{C}_{3} \mathrm{H}_{7}$ from $\mathbf{1}$ is $99 \mathrm{~kJ} \mathrm{~mol}^{-1}$ endothermic.

With regard to the relatively high energy for the strained TS1 we sought alternative pathways for the loss of $\mathrm{C}_{3} \mathrm{H}_{7}$. For example, cis-trans isomerization of the His amide bond introduces a backbone turn, which might allow for facile approach of the Ala- $\mathrm{C}_{\alpha}$ radical center and the Leu- $\mathrm{C}_{\alpha}-\mathrm{H}$ bond. The cis-trans isomerization was examined in quite a detail and several transition states were found that differed in their intramolecular $\mathrm{H}$-bonding patterns. The lowest-energy transition-state (TS3 at $79 \mathrm{~kJ} \mathrm{~mol}^{-1}$ above 1, Table 1) developed a stabilizing hydrogen bond between the $\mathrm{Ala}_{2}$ amide $\mathrm{N}-\mathrm{H}$ and the carboxyl group (Scheme 3 ). The cis-amide isomer 4 was $35 \mathrm{~kJ} \mathrm{~mol}^{-1}$ less stable than $\mathbf{1}$ (Table 1) but had an arrangement of the Ala and Leu $C_{\alpha}$ atoms that favored subsequent hydrogen atom transfer. The corresponding TS4 was only $66 \mathrm{~kJ} \mathrm{~mol}^{-1}$ above 4 and the hydrogen migration was $20 \mathrm{~kJ} \mathrm{~mol}^{-1}$ exothermic to form the Leu- $C_{\alpha}$ radical 5 (Scheme 3). Cleavage of the Leu $C_{\beta}-C_{\gamma}$ bond in 5 can proceed through TS5, which is analogous to TS2 and requires $115 \mathrm{~kJ} \mathrm{~mol}^{-1}$ from 5 . The dissociation energy from 4 to the cis-isomer of the $\mathrm{m} / \mathrm{z}$ 352 fragment ion (6) was $97 \mathrm{~kJ} \mathrm{~mol}^{-1}$. Note that this threshold energy, when referred to $1\left(132 \mathrm{~kJ} \mathrm{~mol}^{-1}\right)$, was higher than that for the trans isomer $\mathbf{3}$, reflecting the lower stability of the His cis-amide group in $\mathbf{6}$.

The competitive elimination of $\mathrm{C}_{4} \mathrm{H}_{8}$ from 1 can proceed by a hydrogen atom transfer from the $\mathrm{C}_{\gamma}$ position of the Leu side chain (Scheme 4). Because of the practically unimpeded rotations about the single $\mathrm{C}-\mathrm{C}$ bonds in the Leu isobutyl group, the TS for the $\mathrm{H}_{\gamma}$-atom transfer (TS6) is substantially less strained than TS1 and requires a lower energy (103 $\mathrm{kJ} \mathrm{mol}^{-1}$ relative to $\mathbf{1}$, Table 1 ). However, the isomerization is endothermic forming $\mathrm{C}_{\gamma}$ radical 7, which is $46 \mathrm{~kJ} \mathrm{~mol}^{-1}$ above 1 . Cleavage of the $C_{\alpha}-C_{\beta}$ bond in 7 is facile and requires only $53 \mathrm{~kJ} \mathrm{~mol}^{-1}$ in the pertinent transitionstate (TS7). Analysis of the potential energy surface after $C_{\alpha}-C_{\beta}$ bond cleavage revealed a local minimum corresponding to an ion-molecule complex (8). However, the combined B3LYP and MP2 energies placed complex 8 at $59 \mathrm{~kJ} \mathrm{~mol}^{-1}$ above 1, which was slightly higher than the dissociation threshold for the elimination of $\mathrm{C}_{4} \mathrm{H}_{8}$ and formation of the $\mathrm{m} / \mathrm{z} 339$ ion $(9,52 \mathrm{~kJ}$ $\mathrm{mol}^{-1}$ relative to 1$)$. We did not pursue this minor topic 

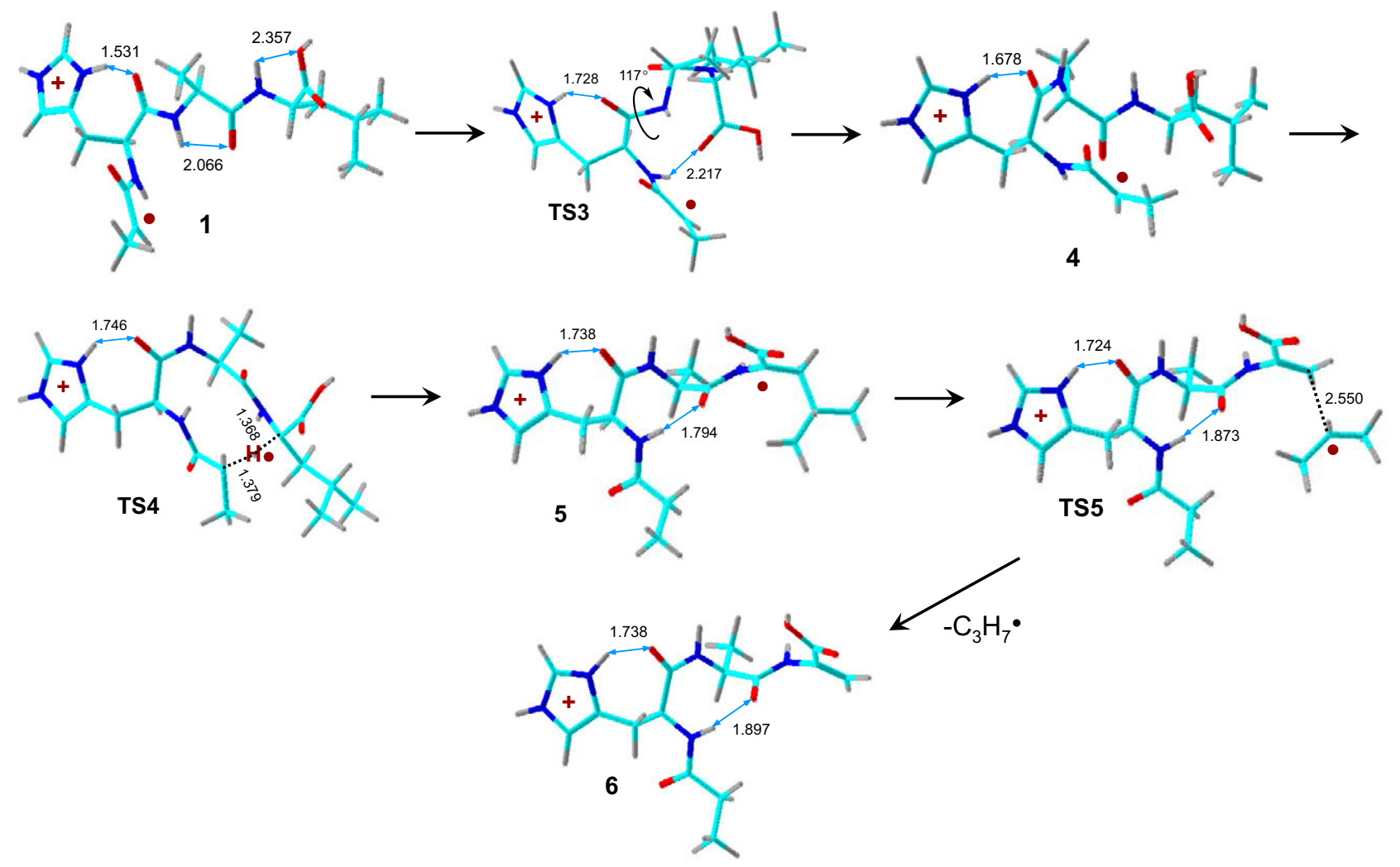

Scheme 3

any further to establish if there were any more stable complexes of the same type. Finally, 1,3-H atom migration between the Leu $\mathrm{C}_{\alpha}$ and $\mathrm{C}_{\gamma}$ positions in 2 and 7 has a high TS energy (TS8, $139 \mathrm{~kJ} \mathrm{~mol}^{-1}$ relative to 7 ) and cannot compete with the loss of $\mathrm{C}_{3} \mathrm{H}_{7}$ and $\mathrm{C}_{4} \mathrm{H}_{8}$. Thus,

Table 1. Relative energies of ${ }^{\bullet} \mathrm{AHAL} z_{4}$ ions

\begin{tabular}{|c|c|c|c|c|}
\hline \multirow[b]{3}{*}{ Ion/reaction } & \multicolumn{4}{|c|}{ Relative energy $\mathrm{y}^{\mathrm{a}, \mathrm{b}}$} \\
\hline & B3LYP & B3LYP & PMP2 & B3-PMP2 \\
\hline & $\begin{array}{l}6-31+ \\
G(d, p)\end{array}$ & \multicolumn{2}{|c|}{$\begin{array}{c}6-311++ \\
\mathrm{G}(2 \mathrm{~d}, \mathrm{p})\end{array}$} & $\begin{array}{c}6-311++ \\
G(2 d, p)\end{array}$ \\
\hline $1 \rightarrow$ TS1 & 154 & 154 & 111 & 132 \\
\hline $1 \rightarrow 2$ & -32 & -33 & -35 & -34 \\
\hline $2 \rightarrow$ TS2 & 121 & 117 & 147 & 132 \\
\hline $\mathbf{1} \rightarrow \mathbf{3}+\mathrm{C}_{3} \mathrm{H}_{7}^{\bullet}$ & 83 & 77 & 120 & 99 \\
\hline $1 \rightarrow 4$ & 44 & 44 & 26 & 35 \\
\hline $1 \rightarrow$ TS3 & 88 & 89 & 70 & 79 \\
\hline $4 \rightarrow$ TS4 & 76 & 77 & 54 & 66 \\
\hline $4 \rightarrow 5$ & -29 & -29 & -11 & -20 \\
\hline $5 \rightarrow$ TS5 & 107 & 103 & 128 & 115 \\
\hline $4 \rightarrow 6+\mathrm{C}_{3} \mathrm{H}_{7}{ }^{\bullet}$ & 73 & 68 & 126 & 97 \\
\hline $1 \rightarrow$ TS6 & 118 & 119 & 87 & 103 \\
\hline $1 \rightarrow 7$ & 50 & 48 & 44 & 46 \\
\hline $7 \rightarrow$ TS7 & 46 & 44 & 62 & 53 \\
\hline $1 \rightarrow 8$ & 48 & 41 & 76 & 59 \\
\hline $\mathbf{1} \rightarrow \mathbf{9}+\mathrm{C}_{4} \mathrm{H}_{8}$ & 35 & 27 & 77 & 52 \\
\hline $7 \rightarrow$ TS8 & 136 & 137 & 140 & 139 \\
\hline
\end{tabular}

an units of $\mathrm{kJ} \mathrm{mol}^{-1}$.

bIncluding $B 3 L Y P / 6-31+G(d, p)$ zero-point energies and referring to $0 \mathrm{~K}$. radicals 2 and 7 are unlikely to interconvert by $1,3-\mathrm{H}$ atom migration.

\section{Competitive Kinetics of AAHAL} $z_{4}$ Ion Dissociations

The ETD-CID-MS ${ }^{3}$ spectrum of the $m / z 395 z_{4}$ ion shows a $0.52: 1$ branching ratio for the eliminations of $\mathrm{C}_{4} \mathrm{H}_{8}$ and $\mathrm{C}_{3} \mathrm{H}_{7}$. We used the B3-PMP2/6-311++G(2d,p) potential energy surface to calculate unimolecular rate constants for the isomerizations and dissociations leading to the eliminations of $\mathrm{C}_{3} \mathrm{H}_{7}$ and $\mathrm{C}_{4} \mathrm{H}_{8}$. Since we placed no experiment-related constraints on the calculated rate constants, the comparison of the calculated and experimental branching ratios can provide a stringent test of the quality of the theoretical potential energy surface. The potential energy surface is visualized in Figure 4, which also shows the rate constants we considered in the kinetic scheme. The loss of $\mathrm{C}_{3} \mathrm{H}_{7}$ was first considered to occur via the reaction sequence: $\mathbf{1} \rightarrow$ TS1 $\rightarrow \mathbf{2} \rightarrow$ TS2 $\rightarrow 3$. The calculated rate constants $\left(k_{1}\right.$ and $k_{2}$, Figure $5 a)$ indicate that the Leu- $\mathrm{C}_{\alpha}-\mathrm{H}$ migration is the rate determining step. However, the pertinent rate constant $\left(k_{1}\right)$ shows a very shallow rise with the ion internal energy and does not reach the value needed for the reaction to proceed on the experimental time scale of 200 ms (broken line in Figure 5). The second pathway that we considered included reversible trans-cis isomerization $\left(k_{3}, k_{-3}\right)$, followed by reversible Leu- $\mathrm{C}_{\alpha}-\mathrm{H}$ mi- 


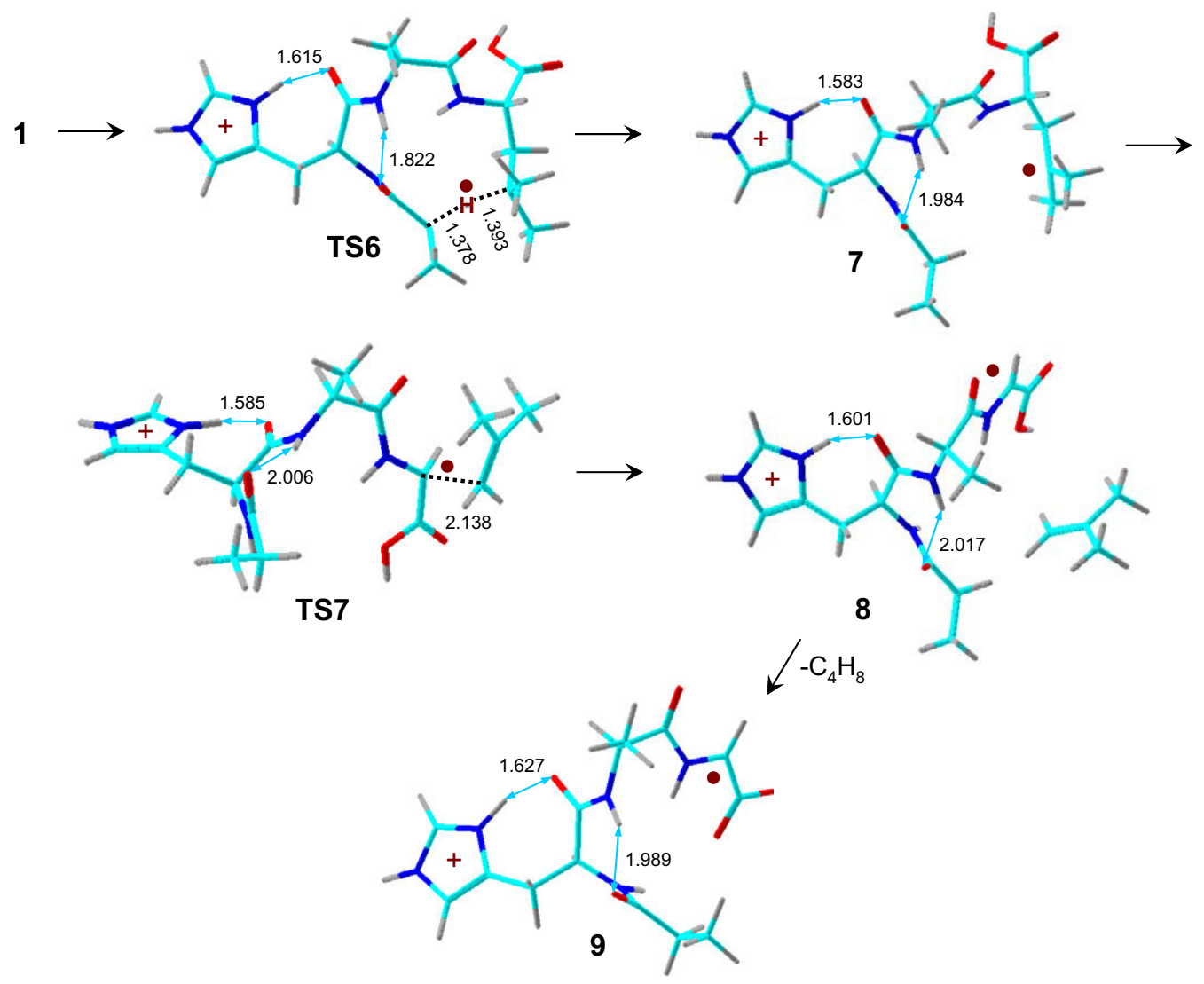

Scheme 4

gration in the cis isomer $4\left(k_{4}, k_{-4}\right)$ followed by $\mathrm{C}_{3} \mathrm{H}_{7}$ dissociation in $5\left(k_{5}\right)$. The calculated rate constants (Figure $5 b$ ) indicate a rapid $1 \leftrightarrow 4$ equilibration through TS3, so that the population of 4 is given by the $k_{3} / k_{-3}$ ratio. The Leu- $\mathrm{C}_{\alpha}-\mathrm{H}$ migration in 4 is also reversible, but the rate constants favor the formation of 5 by $>25$-fold. The competition between the loss of $\mathrm{C}_{3} \mathrm{H}_{7}$ from $5\left(k_{5}\right)$ and reverse isomerization to $4\left(k_{-4}\right)$ is in favor of the dissociation at internal energies $>260 \mathrm{~kJ} \mathrm{~mol}^{-1}$. Under these circumstances, the overall rate constant for the

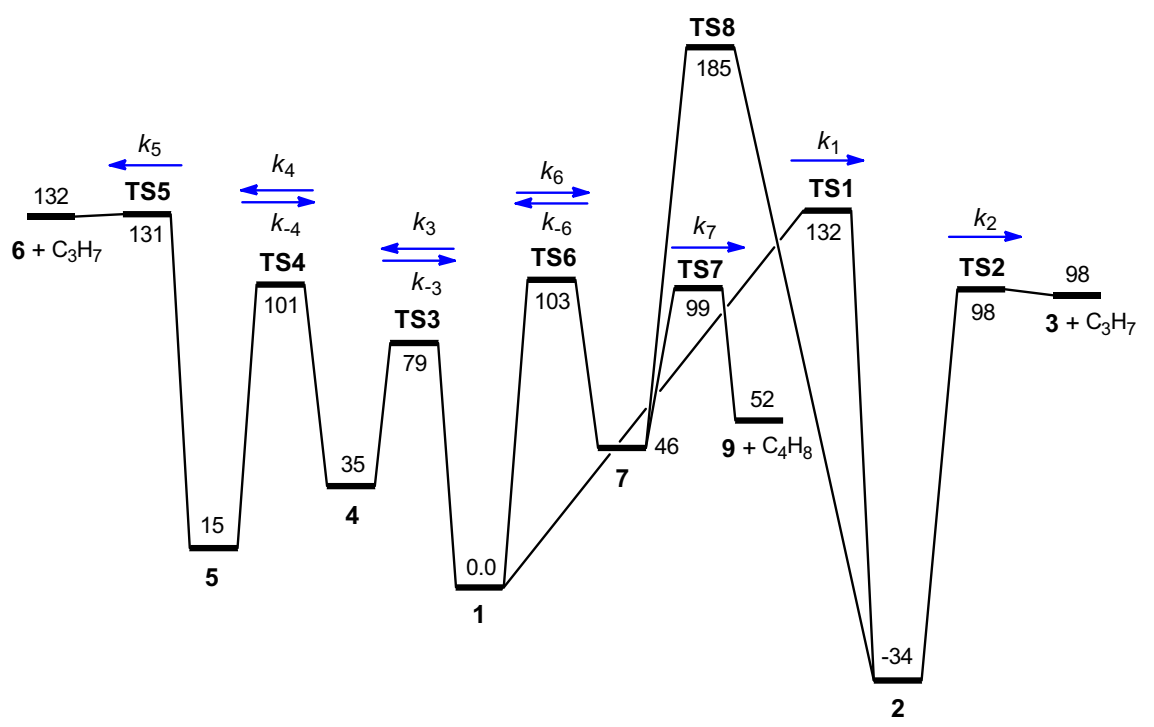

Figure 4. B3-PMP2 $/ 6-311++\mathrm{G}(2 \mathrm{~d}, \mathrm{p})$ potential energy diagram $\left(\mathrm{kJ} \mathrm{mol}^{-1}\right)$ for dissociations and rearrangements of $z_{4}$ ions from AAHAL. The relative and TS energies include B3LYP $/ 6-31+\mathrm{G}(\mathrm{d}, \mathrm{p})$ zero-point vibrational energies. 

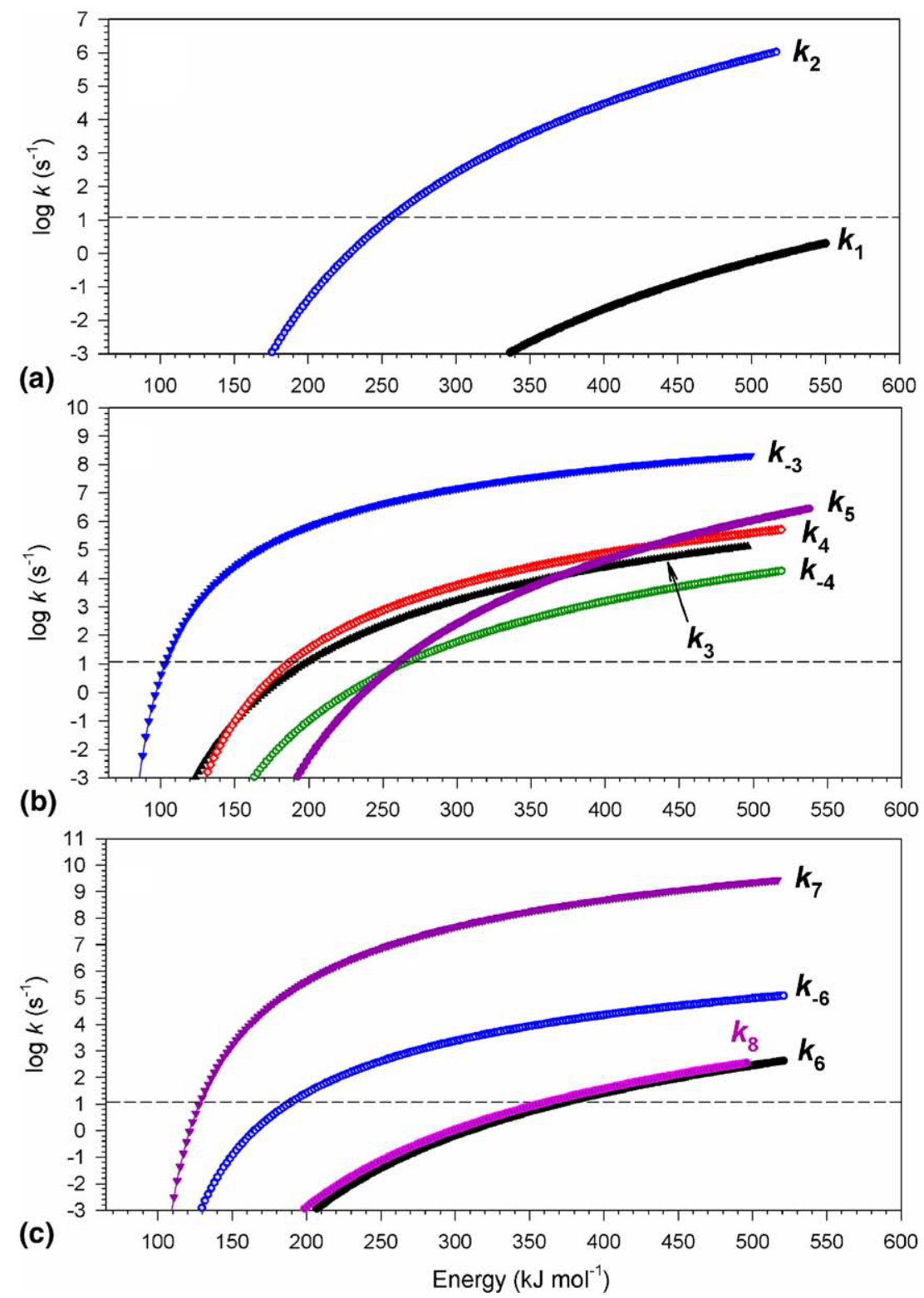

Figure 5. RRKM rate constants. (a) Leu $\mathrm{C}_{\alpha}$ hydrogen migration: $\mathbf{1} \rightarrow \mathrm{TS} 1 \rightarrow 2\left(k_{1}\right)$ and loss of $\mathrm{C}_{3} \mathrm{H}_{7}: 2 \rightarrow$ TS2 $\rightarrow 3$. $\left(k_{2}\right)\left(\right.$ b) Reversible trans-cis amide rotation: $1 \leftrightarrow 4\left(k_{3}, k_{-3}\right)$, reversible Leu $\mathrm{C}_{\alpha}$ hydrogen migration: $4 \rightarrow$ TS4 $\rightarrow 5\left(k_{4}, k_{-4}\right)$, and loss of $\mathrm{C}_{3} \mathrm{H}_{7}: 5 \rightarrow$ TS5 $\rightarrow \mathbf{6}$. $\left(k_{5}\right)$ (c) Reversible Leu $\mathrm{C}_{\gamma}$ hydrogen migration: $1 \rightarrow$ TS6 $\rightarrow 7\left(k_{6}, k_{-6}\right)$, and loss of $\mathrm{C}_{4} \mathrm{H}_{8}: 7 \rightarrow$ TS7 $\rightarrow$ 10. $\left(k_{7}\right)$, and overall rate constant for the loss of $\mathrm{C}_{3} \mathrm{H}_{7}\left(k_{8}\right)$. The broken lines in all three panels indicate the rate constants necessary for $90 \%$ reaction on the 200 ms experimental time scale.

loss of $\mathrm{C}_{3} \mathrm{H}_{7}$ can be written as $k_{8}=\min \left(k_{4} k_{3} / k_{-3}\right.$, $\left.k_{5} k_{3} / k_{-3}\right)$, which is $k_{8}=k_{5} k_{3} / k_{-3}$ for internal energies $<430 \mathrm{~kJ} \mathrm{~mol}^{-1}$ and $k_{8}=k_{4} k_{3} / k_{-3}$ for internal energies $>430 \mathrm{~kJ} \mathrm{~mol}^{-1}$ (Figure 5b). The pertinent overall rate constant $\left(k_{8}\right)$ is plotted in Figure $5 \mathrm{c}$, which also shows the rate constants for the reversible migration of the Leu $\mathrm{C}_{\gamma}$ hydrogen $\left(k_{6}, k_{-6}\right)$ and the loss of $\mathrm{C}_{4} \mathrm{H}_{8}$ from $7\left(k_{7}\right)$. Note that all rate constants in Figure $5 \mathrm{a}-\mathrm{c}$ are plotted on a common energy scale referring to 1 . The Figure $5 c$ data indicate that the rate determining step in the elimination of $\mathrm{C}_{4} \mathrm{H}_{8}$ is the Leu- $\mathrm{C}_{\gamma}$ hydrogen migration in 1 (TS6, $\left.k_{6}\right)$, which is followed by fast bond cleavage in
7 (TS7, $\left.k_{7}\right)$, which outcompetes the reverse H-atom migration (TS6, $k_{-6}$ ) by nearly four orders of magnitude. Hence, the branching ratio for the $\mathrm{C}_{4} \mathrm{H}_{8}$ and $\mathrm{C}_{3} \mathrm{H}_{7}$ eliminations can be expressed as $k_{6} / k_{8}$. The broken line drawn at $\log k=1.06$ in Figure $5 c$ indicates rate constants for dissociations occurring on the experimental time scale (200 ms) with 90\% efficiency, which for $k_{6}$ and $k_{8}$ appears at internal energies around $362 \mathrm{~kJ}$ $\mathrm{mol}^{-1}$.

The calculated branching ratio is plotted as the black curve (a) in Figure 6. At $362 \mathrm{~kJ} \mathrm{~mol}^{-1}$ excitation, 1 is calculated to give a branching ratio of $\left[\mathrm{C}_{4} \mathrm{H}_{8}\right] /\left[\mathrm{C}_{3} \mathrm{H}_{7}\right] \approx$ 


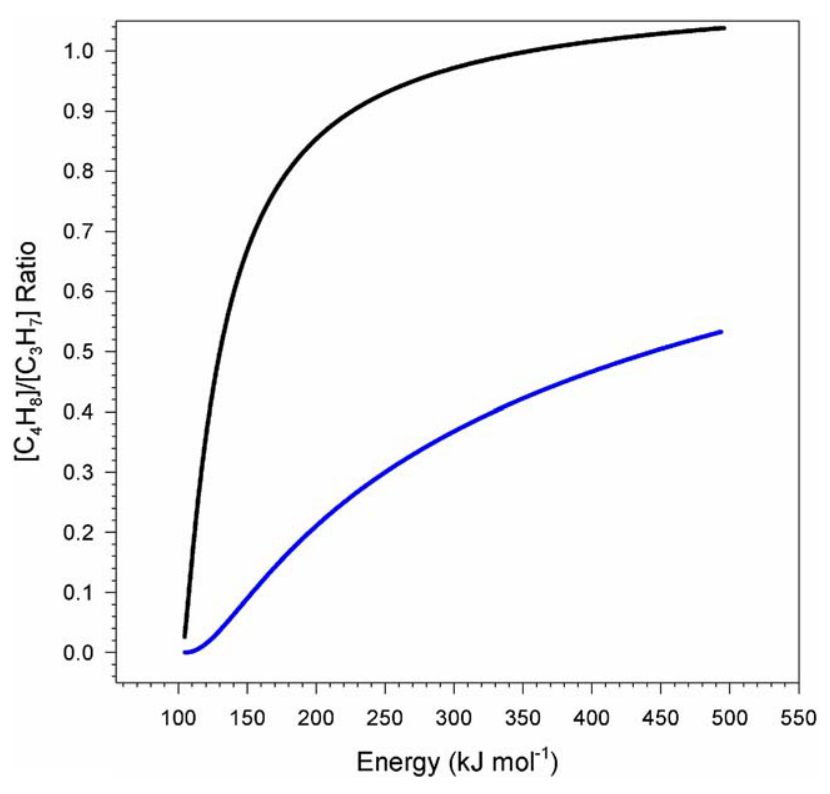

Figure 6. RRKM calculated branching ratios for the $\mathrm{C}_{3} \mathrm{H}_{7}$ and $\mathrm{C}_{4} \mathrm{H}_{8}$ eliminations from 1 . The black curve is for rate constants calculated on the B3-PMP2/6-311++G(2d,p) + ZPVE potential energy surface. The blue curve is for rate constants from TS4 and TS6 energies that were adjusted by $\pm 2 \mathrm{~kJ} \mathrm{~mol}^{-1}$

1.0, which is higher than the experimental value (0.52). The above-described kinetic analysis indicated that the branching ratio is most affected by the rate constants in the rate-determining steps, $k_{4}, k_{5}$, and $k_{6}$, which in turn strongly depend on the respective TS energies.

Energy calculations at high levels of theory aim at what is called the "chemical accuracy," which was defined by Pople and coworkers as $\pm 1 \mathrm{kcal} \mathrm{mol}^{-1}$ $\left( \pm 4.184 \mathrm{~kJ} \mathrm{~mol}^{-1}\right)$ of the actual value [34]. We now apply this criterion to examine how the TS energies calculated within the chemical accuracy affect the branching ratio in Figure 6 . The blue curve (b) shows the branching ratio calculated for RRKM rate constants that were obtained on an adjusted potential energy surface where the TS6 energy was increased by $2 \mathrm{~kJ}$ $\mathrm{mol}^{-1}$ and the TS5 energy was decreased by $2 \mathrm{~kJ} \mathrm{~mol}^{-1}$. These adjusted TS energies are within the Pople's chemical accuracy limit and yield a branching ratio of $\left[\mathrm{C}_{4} \mathrm{H}_{8}\right] /\left[\mathrm{C}_{3} \mathrm{H}_{7}\right]=0.42$. This points out that the calculated branching ratio is very sensitive to the TS energies, and an adjustment within $\pm 2 \mathrm{~kJ} \mathrm{~mol}^{-1}$, which certainly is within the accuracy of the computational methods used here, brings the calculated branching ratio in a complete agreement with experiment. Of course, an opposite adjustment of the pertinent TS energies would change the ratio in favor of the $\mathrm{C}_{4} \mathrm{H}_{8}$ elimination. Nevertheless, one can conclude that the kinetic analysis on the suggested potential energy surface provides a very realistic representation of the competitive and consecutive reactions leading to eliminations of $\mathrm{C}_{4} \mathrm{H}_{8}$ and $\mathrm{C}_{3} \mathrm{H}_{7}$.

\section{Energetics of AHDAL $z_{4}$ Ion Dissociations}

$z$-Type ions from the AHDAL and AHADL peptides undergo competitive losses of water, $\mathrm{C}_{3} \mathrm{H}_{7}, \mathrm{C}_{4} \mathrm{H}_{8}, \mathrm{CO}_{2}$, and the Asp-specific backbone cleavage. Whereas the first three dissociations are common to $z$ ions from the AAHAL, AHDAL, and AHADL sequences, the latter two dissociations are particular to the Asp-containing peptides. We now address the energetics of loss of $\mathrm{CO}_{2}$ and Asp-specific backbone cleavage for the $z_{4}$ ion from AHDAL as a case in point. We first briefly describe the reaction pathways and then compare their energetics and competitiveness.

\section{$\mathrm{CO}_{2}$ Loss}

The $\mathrm{CO}_{2}$ molecule can originate from the Asp or Leu C-terminal carboxyl groups. The loss is presumably triggered by radical-induced rearrangements in the $z$ ions. By comparison, Asp-containing even-electron fragment ions from AHDAL and AHADL were found not to decarboxylate upon CID. We first considered four different pathways $(\boldsymbol{a}-\boldsymbol{d})$ for $\mathrm{CO}_{2}$ elimination from the Asp residue, each starting from a different $z_{4}$ HDAL conformer representing the $m / z 439$ ion. All conformers are protonated in the imidazole ring. The most stable conformer $\mathbf{1 0}$ has a hydrogen bond between the $\mathrm{N}-1^{\prime}-\mathrm{H}$ group of the protonated imidazole ring and the Asp amide carbonyl (Scheme 5, Scheme S2). Interestingly, the acidic imidazole $\mathrm{C}-2^{\prime}-\mathrm{H}$ bond is hydrogen bonded to the C-terminal carboxyl group. The Asp carboxyl group can be activated for $\mathrm{CO}_{2}$ elimination in the following reaction sequences. Ion $\mathbf{1 0}$ first has to undergo a trans-cis amide rotation via TS9 $\left(68 \mathrm{~kJ} \mathrm{~mol}^{-1}\right.$ relative to 10) to form the cis-isomer 11. In path $a$ (Scheme S2), the latter isomerizes by $\mathrm{COOH}$ hydrogen atom migration to the His- $\mathrm{C}_{\alpha}$ radical site (TS10, $169 \mathrm{~kJ}$ $\mathrm{mol}^{-1}$ relative to 10) to produce a high-energy Asp$\mathrm{COO}$ radical (12), which exothermically loses $\mathrm{CO}_{2}$ to form fragment ion 13. Note that the overall loss of $\mathrm{CO}_{2}$ from $\mathbf{1 0}$ is practically thermoneutral (Table 2).

Another possible pathway $(\boldsymbol{b})$ for the loss of $\mathrm{CO}_{2}$ from 11 commences with an Asp- $\mathrm{H}_{\alpha}$ migration to the His- $\mathrm{C}_{\alpha}$ radical site, which proceeds through a fivemembered cyclic transition-state (TS11, $58 \mathrm{~kJ} \mathrm{~mol}^{-1}$ above 11) to form the Asp- $\mathrm{C}_{\alpha}$ radical 14 at $-56 \mathrm{~kJ} \mathrm{~mol}^{-1}$ relative to $\mathbf{1 1}$ (Scheme S3, Table 2). Migration of the Asp-COOH hydrogen atom to the Asp- $\mathrm{C}_{\alpha}$ radical center in 14 requires $177 \mathrm{~kJ} \mathrm{~mol}^{-1}$ in TS12 forming an Asp$\mathrm{COO}$ radical (12), which is followed by an exothermic loss of $\mathrm{CO}_{2}$.

A yet different but energetically similar pathway $(c)$ starts from another $z_{4}$ ion conformer (15) and involves amide cis-trans isomerization to $\mathbf{1 6}, \mathrm{Asp}-\mathrm{H}_{\alpha}$ migration to $17, \mathrm{COOH}$ migration (TS13) to 18 , and exothermic $\mathrm{CO}_{2}$ loss via TS14 to form fragment ion 19 (Scheme S4, Table 2).

A common feature of pathways $a-c$ for Asp $\mathrm{CO}_{2}$ loss from $\mathbf{1 0}$ and $\mathbf{1 5}$ is the existence of relatively high-energy 

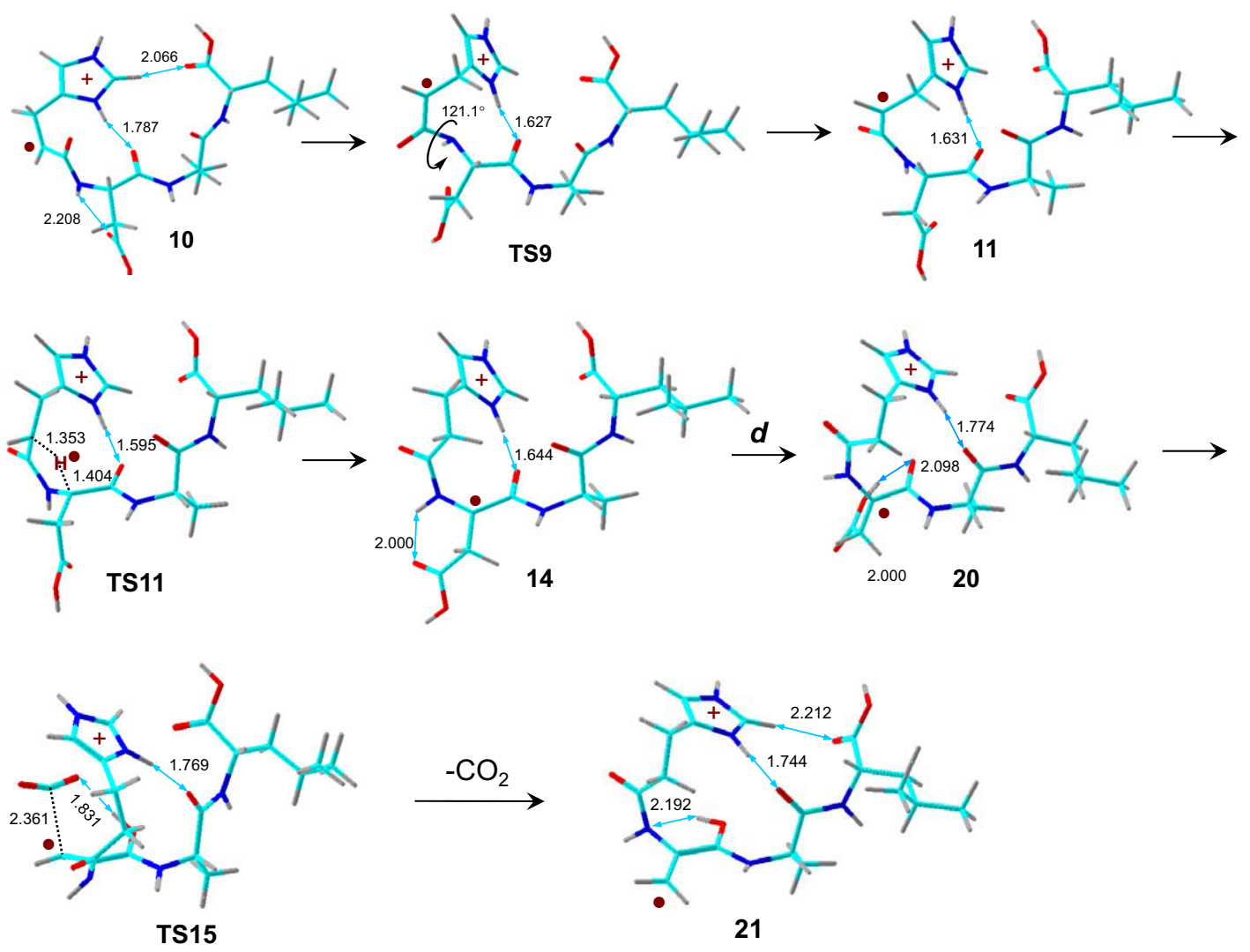

Scheme 5

transition states (TS10, TS12, and TS13) for the carboxyl $\mathrm{H}$-atom transfer to the pertinent $\mathrm{C}_{\alpha}$ radical sites. We therefore examined a fourth pathway $(d)$ where the carboxyl $\mathrm{H}$-atom was transferred to the Asp amide oxygen (Scheme 5). Pathway $d$ starts from Asp- $\mathrm{C}_{\alpha}$ radical 14, which undergoes internal rotations to form a new conformer $\mathbf{2 0}$ in which the $\mathrm{COOH}$ proton is $\mathrm{H}$ bonded to the Asp amide while the protonated His ring is $\mathrm{H}$-bonded to the $\mathrm{Ala}_{4}$ amide (Scheme 5). Conformer 20 is $38 \mathrm{~kJ} \mathrm{~mol}^{-1}$ less stable than $\mathbf{1 4}$ but has a favorable arrangement of the $\mathrm{COOH}$ and amide groups for $\mathrm{H}$ transfer. This $\mathrm{H}$-atom transfer proceeds through a sevenmembered cyclic transition-state $\left(\mathrm{TS} 15,86 \mathrm{~kJ} \mathrm{~mol}^{-1}\right.$ relative to 14) and is accompanied by a concomitant elimination of $\mathrm{CO}_{2}$ forming fragment ion 21. Note that although 21 is $18 \mathrm{~kJ} \mathrm{~mol}^{-1}$ less stable than the isomeric fragment ion 13, the formation of the former requires a substantially lower TS energy ( $64 \mathrm{~kJ} \mathrm{~mol}^{-1}$ from 10) and is likely to be kinetically preferred.

A notable feature of cation-radical $\mathbf{2 1}$ is that it is not an aminoketyl radical in spite of the presence of a $\mathrm{C}(\mathrm{OH}) \mathrm{NH}$ moiety from the decarboxylated Asp residue. Spin analysis [35] of 21 indicates $60 \%$ of oddelectron density at the $C_{\beta}$-methylene of the former Asp residue whereas the enolimine carbon atom has only $36 \%$. In addition, the Asp enolimine moiety in $\mathbf{2 1}$ is planar, which contrasts the typically pyramidal geometries of aminoketyl radicals [36]. These structure and electronic properties of $\mathbf{2 1}$ undoubtedly affect its reac- tivity. For example, CID-MS ${ }^{4}$ of the respective $m / z 395$ ion resulted in major losses of water, $\mathrm{C}_{3} \mathrm{H}_{7}$, and $\mathrm{C}_{4} \mathrm{H}_{8}$, combined with elimination of $\mathrm{CO}_{2}$ (Figure S2). In contrast, an $\mathrm{m} / \mathrm{z} 209$ fragment from an $\mathrm{N}-\mathrm{C}_{\alpha}$ bond dissociation between the decarboxylated Asp and Ala residues was completely absent.

Although the occurrence of $\mathrm{CO}_{2}$ loss from Aspcontaining $z$ ions seems to indicate that the Asp carboxyl group is involved, other pathways are possible starting from the $z_{4}$ conformer 22, but involving the C-terminal $\mathrm{COOH}$ group. The first such pathway we explored (Scheme S5) starts with trans-cis isomerization, $22 \rightarrow$ TS16 $\rightarrow 23$ to form a cis-amide, which is 11 $\mathrm{kJ} \mathrm{mol}^{-1}$ above 22 (Table 2). Migration of the Asp- $\mathrm{H}_{\alpha}$ to the His- $\mathrm{C}_{\alpha}$ position, $23 \rightarrow$ TS17 $\rightarrow 24$, forms the Asp- $C_{\alpha}$ radical, which is practically isoenergetic with 22. Migration of the $\mathrm{C}$-terminal carboxyl hydrogen atom to Asp- $C_{\alpha}$ requires $183 \mathrm{~kJ} \mathrm{~mol}^{-1}$ in TS18, which represents another high-energy transition-state, and results in a spontaneous loss of $\mathrm{CO}_{2}$ forming ion 25 (Scheme S5).

Alternatively, the C-terminal carboxyl can directly reach the His- $\mathrm{C}_{\alpha}$ radical center in $\mathbf{2 2}$ in a conformation that retains all trans amide bonds and facilitates carboxyl hydrogen atom transfer (Scheme 6). The pertinent TS19 requires $85 \mathrm{~kJ} \mathrm{~mol}^{-1}$ from 22, which is substantially lower than the energies for TS10, TS12, and TS13, and comparable to that in TS14. The Leu carboxyl $\mathrm{H}$-atom transfer through TS19 leads to a concomitant 
Table 2. Relative energies of ${ }^{\bullet} \mathrm{HDAL} z_{4}$ ions

\begin{tabular}{|c|c|c|c|c|}
\hline \multirow[b]{3}{*}{ Ion/reaction } & \multicolumn{4}{|c|}{ Relative energy $\mathrm{y}^{\mathrm{a}, \mathrm{b}}$} \\
\hline & \multirow{2}{*}{$\begin{array}{l}\frac{B 3 L Y P}{6-31+} \\
G(d, p)\end{array}$} & B3LYP & PMP2 & \multirow{2}{*}{$\begin{array}{r}\text { B3-PMP2 } \\
6-311++ \\
G(2 d, p)\end{array}$} \\
\hline & & \multicolumn{2}{|c|}{$\begin{array}{c}6-311++ \\
\mathrm{G}(2 \mathrm{~d}, \mathrm{p})\end{array}$} & \\
\hline $10 \rightarrow 11$ & 41 & 41 & 26 & 33 \\
\hline $10 \rightarrow$ TS9 & 69 & 69 & 66 & 68 \\
\hline $10 \rightarrow$ TS10 & 157 & 158 & 180 & 169 \\
\hline $10 \rightarrow 12$ & 81 & 81 & 118 & 99 \\
\hline $10 \rightarrow 13+\mathrm{CO}_{2}$ & 18 & 5 & -6 & -0.5 \\
\hline $11 \rightarrow$ TS11 & 55 & 55 & 60 & 58 \\
\hline $11 \rightarrow 14$ & -62 & -64 & -48 & -56 \\
\hline $14 \rightarrow$ TS12 & 152 & 154 & 200 & 177 \\
\hline $14 \rightarrow 20$ & 42 & 42 & 33 & 38 \\
\hline $10 \rightarrow 15$ & 1 & 0.1 & 19 & 10 \\
\hline $15 \rightarrow 16$ & 23 & 23 & 22 & 22 \\
\hline $15 \rightarrow 17$ & 7 & 9 & 1.5 & 5 \\
\hline $17 \rightarrow$ TS13 & 133 & 134 & 162 & 148 \\
\hline $17 \rightarrow 18$ & 68 & 69 & 104 & 87 \\
\hline $15 \rightarrow$ TS14 & 88 & 87 & 77 & 82 \\
\hline $15 \rightarrow 19+\mathrm{CO}_{2}$ & 16 & 5 & -25 & -10 \\
\hline $14 \rightarrow$ TS15 & 98 & 91 & 81 & 86 \\
\hline $10 \rightarrow$ TS15 & 77 & 68 & 59 & 64 \\
\hline $14 \rightarrow 21+\mathrm{CO}_{2}$ & 51 & 39 & 43 & 41 \\
\hline $10 \rightarrow 21+\mathrm{CO}_{2}$ & 30 & 16 & 21 & 18 \\
\hline $10 \rightarrow 22$ & 21 & 23 & 16 & 19 \\
\hline $22 \rightarrow$ TS16 & 60 & 59 & 63 & 61 \\
\hline $22 \rightarrow 23$ & 11 & 10 & 11 & 11 \\
\hline $22 \rightarrow$ TS17 & 100 & 100 & 94 & 97 \\
\hline $22 \rightarrow 24$ & -2 & -3 & 4 & 0.5 \\
\hline $22 \rightarrow$ TS18 & 167 & 166 & 199 & 183 \\
\hline $22 \rightarrow \mathbf{2 5}+\mathrm{CO}_{2}$ & 9 & -6 & 13 & 3 \\
\hline $22 \rightarrow$ TS19 & 77 & 78 & 93 & 85 \\
\hline $22 \rightarrow 26$ & -53 & -66 & -52 & -59 \\
\hline $16 \rightarrow$ TS20 & 93 & 93 & 82 & 88 \\
\hline $15 \rightarrow 28$ & 32 & 31 & 33 & 32 \\
\hline $16 \rightarrow$ TS21 & 89 & 84 & 111 & 98 \\
\hline $15 \rightarrow 29+30$ & 72 & 66 & 117 & 92 \\
\hline
\end{tabular}

an units of $\mathrm{kJ} \mathrm{mol}^{-1}$.

Including $B 3 L Y P / 6-31+G(d, p)$ zero-point energies and referring to $0 \mathrm{~K}$.

Leu $\mathrm{C}_{\alpha}-\mathrm{COO}$ bond dissociation forming an ion- $\mathrm{CO}_{2}$ complex (26) at $59 \mathrm{~kJ} \mathrm{~mol}^{-1}$ below 22. The $\mathrm{CO}_{2}$ binding energy in 26 is only $20 \mathrm{~kJ} \mathrm{~mol}^{-1}$, so that the complex is presumed to spontaneously dissociate by loss of $\mathrm{CO}_{2}$ to fragment ion 27 when formed through TS19. The absence of a C-terminal COO radical as an intermediate from TS19 is consistent with the low stability of analogous carboxylate radicals from amino acids [37, 38].

\section{Competitive Kinetics of Asp and C-Terminal $\mathrm{CO}_{2}$ Eliminations}

The loss of Asp $\mathrm{CO}_{2}$ through pathway $d$ (Scheme 5) and the loss of the C-terminal $\mathrm{CO}_{2}$ through TS19 (Scheme 6) have comparable TS energies, which raises the question of whether these pathways are kinetically competitive. We carried out RRKM calculations for the pertinent steps and the results are plotted in Figure S1. The loss of the C-terminal $\mathrm{CO}_{2}$ through TS19 shows a very shallow $\log k(E)$ curve indicating an entropically disfavored reaction. Consequently, the $\log k(E)$ curve reaches the kinetically relevant value (log $k=1.06$ for $90 \%$ dissociation on the $0.2 \mathrm{~s}$ experimental time scale) at internal energies $>370 \mathrm{~kJ} \mathrm{~mol}^{-1}$. The loss of the Asp $\mathrm{CO}_{2}$ through pathway $d$ shows two kinetically relevant steps, TS11 and TS15 (Scheme 5), which show comparable rate constants (Figure S1). Treating the pathway $d$ dissociation kinetics as a system of two consecutive reactions (Scheme 5) gave $90 \%$ dissociation at $0.2 \mathrm{~s}$ for reactant internal energies $>196 \mathrm{~kJ} \mathrm{~mol}^{-1}$. In addition, the $k(E)$ curves for TS11 and TS15 showed substantially greater slopes than that for TS19 (Figure S1). The RRKM data imply that the loss of Asp $\mathrm{CO}_{2}$ through pathway $d$ is kinetically favored by $\sim 4$ orders of magnitude over the loss of C-terminal $\mathrm{CO}_{2}$. This is consistent with the experimental data, which show that only the Asp-containing $z$ ions lose $\mathrm{CO}_{2}$ upon collisional activation.

\section{Asp $-C_{\alpha}-\mathrm{CO}$ Bond Cleavage}

According to the mechanism suggested in Scheme 2, this site-specific backbone cleavage is presumably activated by a previous formation of a radical center at the

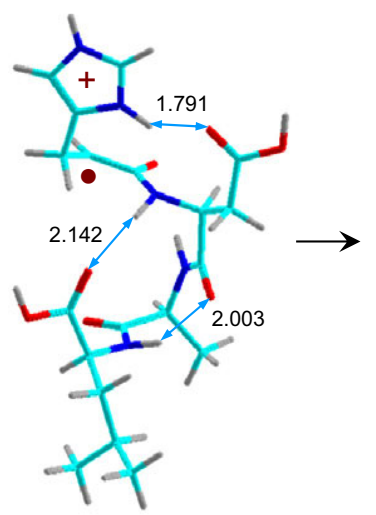

22

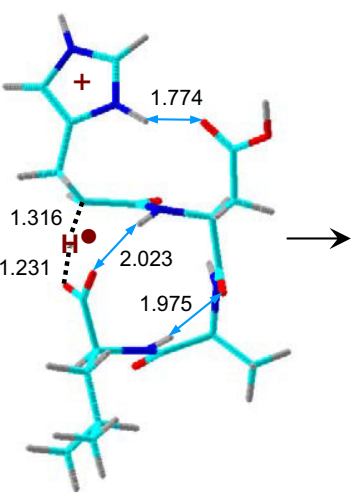

TS19

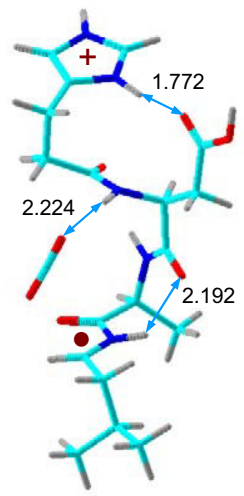

26

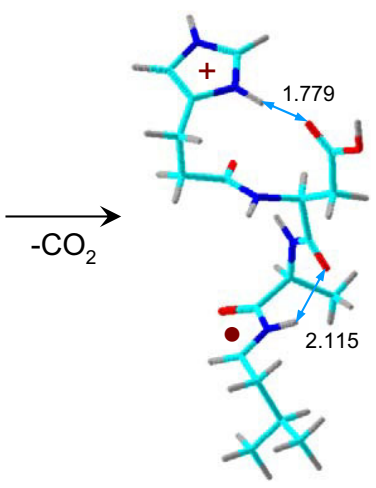

27

Scheme 6 
$\mathrm{C}_{\beta}$ carbon of the Asp side chain. The formation of this radical requires a backbone amide trans-cis isomerization; starting from 15, the isomerization to the cis-amide 16 is $22 \mathrm{~kJ} \mathrm{~mol}^{-1}$ endothermic (Scheme 7, Table 2). The following transfer of an Asp methylene hydrogen atom in 16 requires $88 \mathrm{~kJ} \mathrm{~mol}^{-1}$ in TS20 forming the $\mathrm{C}_{\beta}$ radical 28 at $32 \mathrm{~kJ} \mathrm{~mol}^{-1}$ above 15. Cleavage of the Asp $\mathrm{C}_{\alpha}-\mathrm{CO}$ bond in 28 proceeds through TS21 $\left(98 \mathrm{~kJ} \mathrm{~mol}^{-1}\right)$ to form fragment ion $29(\mathrm{~m} / \mathrm{z} 210)$ and neutral radical fragment 30 at $92 \mathrm{~kJ} \mathrm{~mol}^{-1}$ above 15 .

\section{Discussion}

The computational analysis of the competing dissociations underscores the importance of conformational effects in affecting the transition-state energies and thus directing the ion reactivity. In contrast, dissociation thermochemistry can be a poor predictor of the reaction competitiveness. For example, the loss of $\mathrm{C}_{3} \mathrm{H}_{7}$ from the AAHAL $z_{4}$ ion is $45 \mathrm{~kJ} \mathrm{~mol}^{-1}$ more endothermic than the elimination of $\mathrm{C}_{4} \mathrm{H}_{8}$, and yet the former dissociation is kinetically more favorable. Likewise, the endothermic backbone dissociation of the Asp-C ${ }_{\alpha}-\mathrm{CO}$ bond competes favorably with the exothermic elimination of $\mathrm{CO}_{2}$. These effects are comprehensible only on the basis of a detailed examination of the reaction coordinates, including multiple conformational changes, to pinpoint the rate determining steps and assess their TS energies.

\section{Amide Rotational Barriers}

Owing to the stiffness of the peptide trans-amide backbone, cis-trans amide rotations are often necessary to allow remote groups to approach each other for bondforming reactions such as $\mathrm{H}$-atom transfers (e.g., Scheme 3, S2, S5). The amide rotational barriers in peptides depend on the amino acid residue and can be of both steric and electronic origin [39-41]. In $z$ ions, we observe a marked decrease of energy barriers for amide rotation in the presence of an $\mathrm{C}_{\alpha}$ radical site. For example, the His amide bond rotation in $\mathbf{1}$ has $\mathrm{E}_{\mathrm{TS} 1}=79$ $\mathrm{kJ} \mathrm{mol}^{-1}$, which is close to those in neutral peptides [40] and peptide ions in the gas phase [42]. In contrast, rotation of the His amide bond in $\mathrm{C}_{\alpha}$ radicals $\mathbf{1 0}$ and 22 requires only 68 and $61 \mathrm{~kJ} \mathrm{~mol}^{-1}$, respectively. This barrier lowering is understandable considering canonical amide bond structures (Scheme S6), which show a partial $\mathrm{C}=\mathrm{N}$ double-bond in amides, but less so in amide $\mathrm{C}_{\alpha}$ radicals. This is corroborated by the calculated changes in the $\mathrm{C}-\mathrm{N}$ amide bond lengths. These increase from $1.325 \AA$ in $\mathbf{1}$ to $1.434 \AA$ in the TS for amide rotation (TS1), whereas a smaller increase is found for amide bond rotation in $\mathbf{1 0}(d(\mathrm{C}-\mathrm{N})=1.376 \AA)$ and
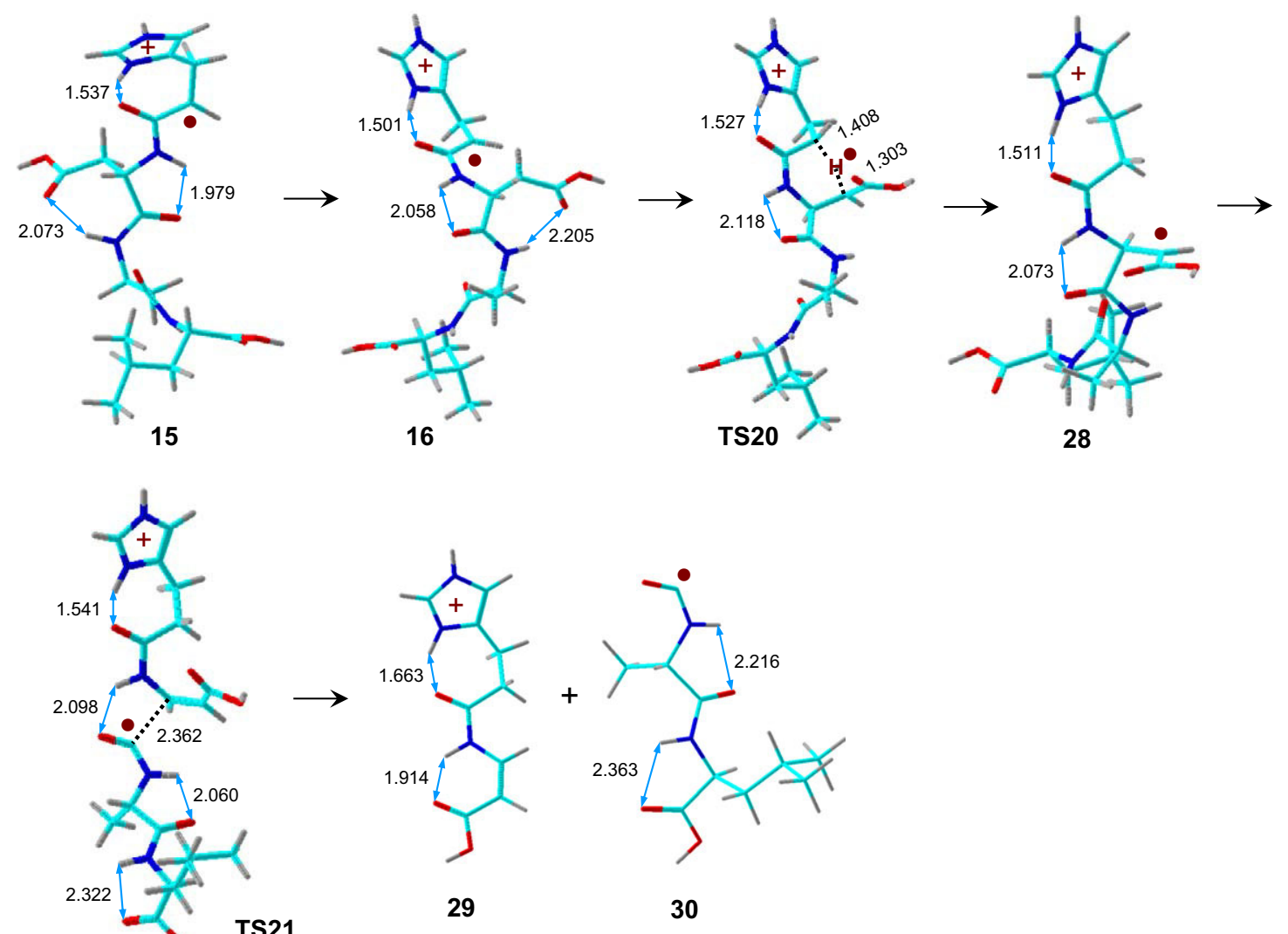

Scheme 7 
the pertinent transition-state, TS9, where $d(\mathrm{C}-\mathrm{N})=$ $1.443 \AA$.

\section{Hydrogen Atom Migrations}

The calculated TS energies indicate that H-atom migrations often are the rate determining steps in $z$ ion dissociations, e.g., Figure 4 . In all cases studied here, the $\mathrm{H}$-atom receptor was a $\mathrm{C}_{\alpha}$ radical site whereas the donors were Asp- $\mathrm{C}_{\alpha}-\mathrm{H}$, Leu- $\mathrm{C}_{\alpha}-\mathrm{H}, \mathrm{Asp}-\mathrm{C}_{\beta}-\mathrm{H}$, Leu$\mathrm{C}_{\gamma}-\mathrm{H}$, and Asp and $\mathrm{C}$-terminal $\mathrm{COOH}$ groups. The TS energies can be expected to be affected by steric effects or ring strain and electronic effects due to the types of covalent bonds to be broken and formed and the associated changes in hydrogen bonding interactions when proceeding from the reactant to the TS. Steric effects are dominant in the Leu- $\mathrm{C}_{\alpha}-\mathrm{H} \rightarrow$ Ala- $\mathrm{C}_{\alpha}$ transfer through TS1 and TS4. Here, the strain imposed on the all-trans amide backbone contributes a $66 \mathrm{~kJ} \mathrm{~mol}^{-1}$ energy increase from $\mathrm{E}_{\mathrm{TS} 4}=66 \mathrm{~kJ} \mathrm{~mol}^{-1}$ in the cis amide to $\mathrm{E}_{\mathrm{TS} 1}=132 \mathrm{~kJ} \mathrm{~mol}^{-1}$ in the trans amide. The steric strain is somewhat relieved in the Leu- $\mathrm{C}_{\gamma}-\mathrm{H} \rightarrow$ Ala- $\mathrm{C}_{\alpha}$. transfer $\left(\mathrm{E}_{\mathrm{TS} 6}=103 \mathrm{~kJ} \mathrm{~mol}^{-1}\right)$ due to the flexibility of the Leu side chain.

$\mathrm{H}$-atom transfer from the $\mathrm{COOH}$ groups seems to be mainly affected by electronic effects. Thus, the Asp$\mathrm{COOH} \rightarrow \mathrm{Asp}-\mathrm{C}_{\alpha}$ transfer proceeds through a fivemembered cyclic TS, which does not allow alignment of the $\mathrm{O} \ldots \mathrm{H} \ldots \mathrm{C}_{\alpha}$ atoms in TS12 and requires the highest energy $\left(\mathrm{E}_{\mathrm{TS} 12}=177 \mathrm{~kJ} \mathrm{~mol}^{-1}\right)$. The analogous Asp-COOH $\rightarrow$ His- $_{\alpha}$ transfer proceeds through an eight-membered cyclic TS, which allows for a more favorable $\mathrm{O} \ldots \mathrm{H} \ldots \mathrm{C}_{\alpha}$ angle $\left(173^{\circ}\right.$ in TS10) and has a lower TS energy $\left(\mathrm{E}_{\mathrm{TS} 10}=136 \mathrm{~kJ} \mathrm{~mol}^{-1}\right)$. The Leu$\mathrm{COOH} \rightarrow \mathrm{His}^{-\mathrm{C}_{\alpha}}$ and Leu-COOH $\rightarrow$ Asp-C $\mathrm{C}_{\alpha}$ transfers proceed through large-ring cyclic TS (TS18 and TS19, respectively) and both have low TS energies, $\mathrm{E}_{\mathrm{TS}}=85 \mathrm{~kJ}$ $\mathrm{mol}^{-1}$. It should be noted that both TS18 and TS19 gain some stabilization from hydrogen bonding of the donor $\mathrm{COOH}$ groups (Scheme 6 and Scheme S5).

The $\mathrm{C}_{\alpha}-\mathrm{H} \rightarrow \mathrm{C}_{\alpha}$ hydrogen migrations show a 58-86 $\mathrm{kJ} \mathrm{mol}{ }^{-1}$ range of TS energies. The five-membered cyclic TS for the Asp- $\mathrm{C}_{\alpha}-\mathrm{H} \rightarrow$ His- $_{\alpha}$ (TS11 and TS17) migrations appear to be electronically similar yet have different TS energies. The difference can be ascribed to the different stabilization of the TS by hydrogen bonding. Thus, the His- $\mathrm{H}^{+} \ldots \mathrm{O}=\mathrm{C}$ hydrogen bond in 23 (1.790 $\AA$, Scheme S5) is stretched to $1.805 \AA$ in TS17. By contrast, the analogous H-bond in $11(1.631 \AA$, Scheme 5) becomes shorter in TS11 (1.595 $\AA$, Scheme S3), presumably contributing to TS stabilization. The Asp$\mathrm{C}_{\beta}-\mathrm{H} \rightarrow$ His- $_{\alpha}$ migration proceeds through a sixmembered cyclic transition-state (TS20, Scheme 7) in which there is loss of H-bonding of the Asp carboxyl group and weakening of the H-bonding of the protonated His ring. These effects presumably contribute to the TS energy, $\mathrm{E}_{\mathrm{TS} 20}=88 \mathrm{~kJ} \mathrm{~mol}^{-1}$. We also note that the energy barriers for $\mathrm{H}$-atom migrations in $z$ ions are substantially lower than those reported by Siu and coworkers for analogous $\mathrm{H}$-atom migrations in triglycine $\mathrm{C}_{\alpha}$ cation-radicals [43]. Whether this difference is of a general nature and applies to other peptide sequences remains to be explored.

\section{Absence of Cascade Fragmentations}

The fact that we observe no cascade fragmentations of the $z_{\mathrm{n}}$ ions from AAHAL, AHDAL, and AHADL is of interest because analogous $z_{\mathrm{n}} \rightarrow z_{\mathrm{m}}(n>\mathrm{m})$ transitions have been observed in ETD-CID spectra of other peptides [6]. Although neither the mechanism(s) of cascade fragmentations [18] nor the reason for their absence are understood, it is safe to say that they are not kinetically competitive in the peptide $z$ ions studied here vis-a-vis the facile dissociations of the Leu and Asp side chains and backbone cleavage at the Asp residue. In contrast, spin-remote backbone dissociations [33] resulting in the eliminations of Leu, Ala-Leu, and Asp-Leu neutral molecules from the $z$ ion C-termini occur competitively with the side chain and Asp-C $-\mathrm{CO}$ cleavages.

\section{Conclusions}

Collisional activation of $z$ ions from electron-transfer dissociation of doubly protonated pentapeptides AAHAL, AHDAL, and AHADL produces two kinds of dissociations. Dissociations of the first kind are accompanied by proton migrations, occur at amide bonds, which are remote from the $\mathrm{C}_{\alpha}$ radical site (spin-remote dissociations), and result in losses of amino acids or small peptides from the C-terminal residues. Dissociations of the second kind involve the $C_{\alpha}$ radical sites and are accompanied by hydrogen atom migrations and transcis amide group isomerizations. These radical dissociations result in side-chain losses of $\mathrm{C}_{3} \mathrm{H}_{7}, \mathrm{C}_{4} \mathrm{H}_{8}, \mathrm{CO}_{2}$, and a specific Asp- $\mathrm{C}_{\alpha}-\mathrm{CO}$ backbone cleavage. Quantum chemistry calculations explain detailed mechanisms of the radical-induced dissociations and, when combined with RRKM calculations, provide branching ratios, which are in close quantitative agreement with experimental data.

\section{Acknowledgments}

The authors acknowledge support of this research by the National Science Foundation (grants CHE-0750048 for experiments and CHE-0342956 for computations). The Department of Chemistry Computational Center has been supported jointly by the NSF and University of Washington. Joshua Gregersen and Christopher Moss provided assistance with RRKM and ab initio calculations. Thanks are also due to Dr. Priska von Haller and the University of Washington Proteomics Mass Spectrometry Resource for providing access to and assistance with the LTQ-ETD mass spectrometer. 


\section{Appendix A Supplementary Material}

Supplementary material associated with this article may be found in the online version at doi:10.1016/ j.jasms.2010.02.018.

\section{References}

1. Syka, J. E. P.; Coon, J. J.; Schroeder, M. J.; Shabanowitz, J.; Hunt, D. F. Peptide and protein sequence analysis by electron transfer dissociation mass spectrometry. Proc. Natl. Acad. Sci. U.S.A. 2004, 101, 9528-9533.

2. Coon, J. J.; Ueberheide, B.; Syka, J. E. P.; Dryhurst, D. D.; Ausio, J.; Shabanowitz, J.; Hunt, D. F. Protein Identification Using Sequential Ion/Ion Reactions and Tandem Mass Spectrometry. Proc. Natl. Acad. Sci. U.S.A. 2005, 102, 9463-9468.

3. Pitteri, S. J.; Chrisman, P. A.; Hogan, J. M.; McLuckey, S. A. Electron Transfer Ion/Ion Reactions in a Three-Dimensional Quadrupole Ion Trap: Reactions of Doubly and Triply Protonated Peptides with $\mathrm{SO}_{2}^{-}$. Anal. Chem. 2005, 77, 1831-1839.

4. McLafferty, F. W.; Tureček, F. Interpretation of Mass Spectra, 4th ed.; University Science Books: Mill Valley, CA, 1993; p. 37-38

5. Hubler, S. L.; Jue, A.; Keith, J.; McAlister, G. C.; Craciun, G.; Coon, J. J. Valence Parity Renders z-Type Ions Chemically Distinct. J. Am. Chem. Soc. 2008, 130, 6388-6394.

6. Han, H.; Xia, Y.; McLuckey, S. A. Ion Trap Collisional Activation of c and $\mathrm{z}$. ions Formed Via Gas-Phase Ion/Ion Electron Transfer Dissociation. J. Proteome Res. 2007, 6, 3062-3069.

7. Cooper, H. J.; Hudgins, R. R.; Hakansson, K.; Marshall, A. G. Characterization of Amino Acid Side-Chain Losses in Electron Capture Dissociation. J. Am. Soc. Mass Spectrom. 2002, 13, 241-249.

8. Cooper, H. J.; Hakansson, K.; Marshall, A. G.; Hudgins, R. R.; Haselmann, K. F.; Kjeldsen, F.; Budnik, B. A.; Polfer, N. C.; Zubarev, R. A. Letter: The Diagnostic Value of Amino Acid Side-Chain Losses in Electron Capture Dissociation of Polypeptides. Comment on: "Can the (M.bul.-X) Region in Electron Capture Dissociation Provide Reliable Information on Amino Acid Composition of Polypeptides?" Eur. J. Mass Spectrom. 2002, 8, 461-469. Eur. J. Mass Spectrom. 2003, 9, 221-222.

9. Kjeldsen, F.; Haselmann, K. F.; Sørensen, E. S.; Zubarev, R. A. Distinguishing of Ile/Leu Amino Acid Residues in the PP3 Protein by (Hot) Electron Capture Dissociation in Fourier Transform Ion Cyclotron Resonance Mass Spectrometry. Anal. Chem. 2003, 75, 1267-1274.

10. Kjeldsen, F.; Zubarev, R. A. Secondary Losses Via $\gamma$-Lactam Formation in Hot Electron Capture Dissociation: A Missing Link to Complete de Novo Sequencing of Proteins? I. Am. Chem. Soc. 2003, 125, 6628-6629.

11. Fung, Y. M. E.; Chan, T.-W. D. Experimental and Theoretical Investigations of the Loss of Amino Acid Side Chains in Electron Capture Dissociation of Model Peptides. J. Am. Soc. Mass Spectrom. 2005, 16, 1523-1535.

12. Savitski, M. M.; Nielsen, M. L.; Zubarev, R. A. Side-Chain Losses in Electron Capture Dissociation To Improve Peptide Identification. Anal. Chem. 2007, 79, 2296-2302.

13. Zubarev, R. A.; Horn, D. M.; Fridriksson, E. K.; Kelleher, N. L.; Kruger, N. A.; Lewis, M. A.; Carpenter, B. K.; McLafferty, F. W. Electron Capture Dissociation for Structural Characterization of Multiply Charged Protein Cations. Anal. Chem. 2000, 72, 563-573.

14. Frison, G.; Bull, A.; van der Rest, G.; Tureček, F.; Besson, T.; Lemaire, J.; Maître, P.; Chamot-Rooke, J. Structure of ECD Fragments from ChargeTagged Peptides Probed by Tunable IRMPD. J. Am. Chem. Soc. 2008, 130, 14916-14917.

15. Tureček, F.; Syrstad, E. A.; Seymour, J. L.; Chen, X.; Yao, C. Peptide Cation-Radicals. A Computational Study of the Competition Between Peptide $\mathrm{N}-\mathrm{C}_{\alpha}$ Bond Cleavage and Loss of the Side Chain in the [GlyPhe- $\left.\mathrm{NH}_{2}+2 \mathrm{H}\right]^{+}$. Cation Radical. J. Mass Spectrom. 2003, 38, 1093-1104.

16. (a) Tureček, F.; Carpenter, F. H.; Polce, M. J.; Wesdemiotis, C. Glycyl Radical Is a Stable Species in the Gas Phase. J. Am. Chem. Soc. 1999, 121, 7955-7956. (b) Carpenter, F. H.; Tureček, F. Glycine Radicals in the Gas Phase. J. Chem. Soc. Perkin Trans. 1999, 2, 2315-2323. (c) O'Hair, R. A. J. Blanksby, S. J.; Styles, M.; Bowie, J. H. Characterization of [M - H] Cations, Radicals, and Anions of Glycine in the Gas Phase: A combined Experimental and $\mathrm{Ab}$ Initio Study. Int. J. Mass Spectrom. 1999, 182/183, 203-211. (d) Polce, M. J.; Wesdemiotis, C. $\alpha$-Glycyl Cation, Radical, and Anion $\left(\mathrm{H}_{2} \mathrm{NCH}^{+} \mathrm{COOH}\right)$ : Generation and Characterization in the Gas Phase. J. Am. Soc. Mass Spectrom. 1999, 10, 1241-1247.

17. Tureček, F.; Chung, T. W.; Wyer, J. A.; Ehlerding, A.; Zettergen, H.; Nielsen, S. B.; Hvelplund, P.; Chamot-Rooke, J.; Bythell, B.; Paizs, B. ECD and ETD are Different. Keynote lecture presented at the 7 th UPPCON Conference, Nara, Japan, December, 2009.

18. Leymarie, N.; Costello, C. E.; O'Connor, P. B. Electron Capture Dissociation Initiates a Free Radical Reaction Cascade. J. Am. Chem. Soc. 2003, 125, 8949-8958.

19. Frisch, M. J.; Trucks, G. W.; Schlegel, H. B.; Scuseria, G. E.; Robb, M. A.; Cheeseman, J. R. Montgomery, J. A. Jr.; Vreven, T.; Kudin, K. N. Burant, J. C.; Millam, J. M.; Iyengar, S. S.; Tomasi, J.; Barone, V.;
Mennucci, B.; Cossi, M.; Scalmani, G.; Rega, N.; Petersson, G. A.; Nakatsuji, H.; Hada, M.; Ehara, M.; Toyota, K.; Fukuda, R.; Hasegawa, J.; Ishida, M.; Nakajima, T.; Honda, Y.; Kitao, O.; Nakai, H.; Klene, M. Li, X.; Knox, J. E.; Hratchian, H. P.; Cross, J. B.; Adamo, C.; Jaramillo, J.; Gomperts, R.; Stratmann, R. E.; Yazyev, O.; Austn, A. J.; Cammi, R.; Pomelli, C.; Ochterski, J. W.; Ayala, P. Y.; Morokuma, K.; Voth, G. A.; Salvador, P.; Dannenberg, J. J.; Zakrzewski, V. G.; Dapprich, S. Daniels, A. D.; Strain, M. C.; Farkas, O.; Malick, D. K.; Rabuck, A. D.; Raghavachari, K.; Foresman, J. B.; Ortiz, J. V.; Cui, Q.; Baboul, A. G.; Clifford, S.; Cioslowski, J.; Stefanov, B. B.; Liu, G.; Liashenko, A.; Piskorz, P.; Komaromi, I.; Martin, R. L.; Fox, D. J.; Keith, T.; Al-Laham, M. A.; Peng, C. Y.; Nanayakkara, A.; Challacombe, M.; Gill, P. M. W.; Johnson, B.; Chen, W.; Wong, M. W.; Gonzalez, C.; Pople, J. A. Gaussian 03, Revision B 05; Gaussian, Inc.; Pittsburgh, PA, 2003.

20. (a) Becke, A. D. A New Mixing of Hartree-Fock and Local DensityFunctional Theories. J. Chem. Phys. 1993, 98, 1372-1377. (b) Becke, A. D. Density Functional Thermochemistry. III. The Role of Exact Exchange. J. Chem. Phys. 1993, 98, 5648-5652. (c) Stephens, P. J.; Devlin, F. J.; Chabalowski, C. F.; Frisch, M. J. Ab Initio Calculation of Vibrational Absorption and Circular Dichroism Spectra Using Density Functional Force Fields. J. Phys. Chem. 1994, 98, 11623-11627.

21. Møller, C.; Plesset, M. S. A Note on an Approximation Treatment for Many-Electron Systems. Phys. Rev. 1934, 46, 618-622.

22. (a) Schlegel, H. B. Potential Energy Curves Using Unrestricted MollerPlesset Perturbation Theory with Spin Annihilation. J. Chem. Phys. 1986, 84, 4530-4534. (b) Mayer, I. Spin-Projected UHF Method. IV. Comparison of Potential Curves Given by Different One-Electron Methods. Adv. Quantum Chem. 1980, 12, 189-262.

23. Tureček, F. Proton Affinity of Dimethyl Sulfoxide and Relative Stabilities of $\mathrm{C}_{2} \mathrm{H}_{6} \mathrm{OS}$ Molecules and $\mathrm{C}_{2} \mathrm{H}_{7} \mathrm{OS}^{+}$Ions. A Comparative G2(MP2) $\mathrm{Ab}$ Initio and Density Functional Theory Study. J. Phys. Chem. A 1998, 102, 4703-4713

24. Gilbert, R.G.; Smith, S. C. Theory of Unimolecular and Recombination Reactions; Blackwell Scientific Publications: Oxford, 1990; p. 52-132.

25. Zhu, L.; Hase, W. L. Quantum Chemistry Program Exchange; Indiana University: Bloomington, 1994; Program No. QCPE 644.

26. Frank, A. J.; Sadílek, M.; Ferrier, J. G.; Tureček, F. Sulfur Oxyacids and Radicals in the Gas Phase. A Variable-Time NeutralizationPhotoexcitation-Reionization Mass Spectrometric and $\mathrm{Ab}$ Initio/ RRKM Study. J. Am. Chem. Soc. 1997, 119, 12343-12353.

27. Holm, A. I. S.; Hvelplund, P.; Kadhane, U.; Larsen, M. K.; Liu, B.; Nielsen, S. B.; Panja, S.; Pedersen, J. M.; Skrydstrup, T.; Støchkel, K.; Williams, E. R.; Worm, E. S. On the Mechanism of Electron-CaptureInduced Dissociation of Peptide Dications from ${ }^{15} \mathrm{~N}$-Labeling and Crown-Ether Complexation. J. Phys. Chem. A 2007, 111, 9641-9643.

28. Paizs, B.; Suhai, S. Fragmentation Pathways of Protonated Peptides. Mass Spectrom. Rev. 2005, 24, 508-548.

29. (a) Yalcin, T.; Khouw, C.; Czizmadia, I. G.; Peterson, M. R.; Harrison A. G. Why Are b Ions Stable Species in Peptide Spectra? J. Am. Soc. Mass Spectrom. 1995, 6, 1165-1174. (b) Rodriquez, C. F.; Shoeib, T.; Chu, I. K.; Siu, K. W. M.; Hopkinson, A. C. Comparison Between Protonation, Lithiation, and Argentation of 5-Oxazolones: A Study of a Key Intermediate in Gas-Phase Peptide Sequencing. I. Phys. Chem. A 2000, 104, 5335-5342. (c) Paizs, B.; Szlavik, Z.; Lendevay, G.; Vekey, K.; Suhai, S. Formation of $\mathrm{a}_{2}^{+}$Ions of Protonated Peptides. An Ab Initio Study. Rapid Commun. Mass Spectrom. 2000, 14, 746-755. (d) Nold, M. J.; Wesdemiotis, C.; Yalcin, T.; Harrison, A. G. Amide Bond Dissociation in Protonated Peptides. Structures of the N-Terminal Ionic and Neutral Fragments. Int. J. Mass Spectrom. Ion Processes. 1997, 164, 137-153. (e) Bythell, B. J.; Somogyi, A.; Paizs, B. What is the Structure of $b_{2}$ Ions Generated from Doubly Protonated Tryptic Peptides? J. Am. Soc. Mass Spectrom. 2009, 20, 618-624. (f) Cooper, H. J. Investigation of the Presence of b Ions in Electron Capture Dissociation Mass Spectra. J. Am. Soc. Mass Spectrom. 2005, 16, 1932-1940.

30. Chen, X.; Tureček, F. Simple. b Ions Have Oxazolone Structures. A Neutralization-Reionization and Computational Study of Oxazolone Radicals. J. Am. Soc. Mass Spectrom. 2005, 16, 1941-1956.

31. Farrugia, J. M.; O'Hair, R. A. J.; Reid, G. E. Do All $b_{2}$ Ions Have Oxazolone Structures? Multistage Mass Spectrometry and Ab Initio Studies on Protonated N-Acyl Amino Acid Methyl Ester. Int. J. Mass Spectrom. 2001, 210/211, 71-87.

32. Perkins, B. R.; Chamot-Rooke, J.; Yoon, S. H.; Gucinski, A. C.; Somogyi, A.; Wysocki, V. H. Evidence of Diketopiperazine and Oxazolone Structures for $\mathrm{HA} \mathrm{b}_{2}^{+}$Ion. J. Am. Chem. Soc. 2009, 131, 17528-17529.

33. Seymour, J. L.; Tureček, F. Structure, Energetics, and Reactivity of Ternary Complexes of Amino Acids with Cu(II) and 2,2'-Bipyridine by Density Functional Theory. A Combination of Radical-Induced and Spin-Remote Fragmentations. J. Mass Spectrom. 2002, 37, 533-540.

34. (a) Pople, J. A.; Head-Gordon, M.; Fox, D. J.; Raghavachari, K.; Curtiss, L. A. Gaussian-1 Theory: A General Procedure for Prediction of Molecular Properties. J. Chem. Phys. 1989, 90, 5622-5629. (b) Curtiss, L. A.; Jones, C.; Trucks, G. W.; Raghavachari, K.; Pople, J. A. Gaussian-1 Theory of Molecular Energies for Second-Row Compounds. J. Chem. Phys. 1990, 93, 2537-2545. (c) Curtiss, L. A.; Raghavachari, K.; Pople, J. A. Gaussian-2 Theory Using Reduced Møller-Plesset Orders. J. Chem. Phys. 1993, 98, 1293-1298. (d) Curtiss, L. A.; Raghavachari, K.; Redfern, P. C.; Rassolov, V.; Pople, J. A. Gaussian-3 (G3) Theory for Molecules Containing First and Second Row Atoms. J. Chem. Phys. 1998, 109, 764-7776. 
35. Reed, A. E.; Weinstock, R. B.; Weinhold, F. Natural Population Analysis. J. Chem. Phys, 1985, 83, 735-746.

36. (a) Syrstad, E. A.; Tureček, F. Hydrogen Atom Adducts to the Amide Bond. Generation and Energetics of the Amino(hydroxy)Methyl Radical in the Gas Phase. J. Phys. Chem. A 2001, 105, 11144-11155. (b) Syrstad, E. A.; Stephens, D. D.; Tureček, F. Hydrogen Atom Adducts to the Amide Bond. Generation and Energetics of Amide Radicals in the Gas Phase. J. Phys. Chem. A 2003, 107, 115-126. (c) Tureček, F.; Syrstad, E. A. Mechanism and Energetics of Intramolecular Hydrogen Transfer Atom Transfer in Amide and Peptide Radicals and Cation-Radicals. J. Am.

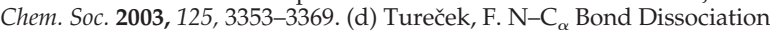
Energies and Kinetics in Amide and Peptide Radicals. Is the Dissociation a Non-Ergodic Process? J. Am. Chem. Soc. 2003, 125, 59545963. (e) Tam, F.; Syrstad, E. A.; Chen, X.; Tureček, F. Electron-Rich Radicals by Neutralization-Reionization Mass Spectrometry. Generation, Dissociations, and Energetics of the Hydrogen Atom Adduct to Acetamide. Eur. J. Mass Spectrom. 2004, 10, 869-879.

37. Yu, D.; Rauk, A.; Armstrong, D. A. Radicals and Ions of Glycine: An Ab Initio Study of the Structures and Gas-Phase Thermochemistry. J. Am. Chem. Soc. 1995, 117, 1789-1796.
38. Moran, D.; Jacob, R.; Wood, G. P. F.; Coote, M. L.; Davies, M. J.; O'Hair, R. A. J.; Easton, C. J.; Radom, L. Rearrangements in Model Peptide-Type Radicals Via Intramolecular Hydrogen-Atom Transfer. Helv. Chim. Acta 2006, 89, 2254-2272.

39. Jhon, J. S.; Kang, Y. K. Imide Cis-Trans Isomerization of N-Acetyl-N'Methylprolineamide and Solvent Effects. J. Phys. Chem. A 1999, 103, 5436-5439.

40. Shi, T.; Spain, S. M.; Rabenstein, D. L. Unexpectedly Fast Cis-Trans Isomerization of Xaa-Pro Peptide Bonds in Disulfide-Constrained Cyclic Peptides. J. Am. Chem. Soc. 2004, 126, 790-796.

41. Fischer, G. Chemical Aspects of Peptide Bond Isomerization. Chem. Soc. Rev. 2000, 29, 119-127.

42. Hayakawa, S.; Hashimoto, M.; Matsubara, H.; Tureček, F. Dissecting the Proline Effect: Dissociations of Proline Radicals Formed by Electron Transfer to Protonated Pro-Gly and Gly-Pro Dipeptides in the Gas Phase. J. Am. Chem. Soc. 2007, 129, 7936-7949.

43. Chu, I. K. Zhao, J: Xu, M.; Siu, S. O. Hopkinson, A. C. Siu, K. W. M. Are the Radical Centers in Peptide Radical Cations Mobile? The Generation, Tautomerism, and Dissociation of Isomeric $\alpha$-CarbonCentered Triglycine Radical Cations in the Gas Phase. J. Am. Chem. Soc. 2008, 130, 7862-7872. 